\title{
SYSTEMATIC METHOD FOR MONITORING AND EARLY-WARNING OF GARDEN HERITAGE ONTOLOGY USED IN THE SUZHOU CLASSICAL GARDEN HERITAGE
}

\author{
Jie $\mathrm{ZHAO}^{1}$, Rikun $\mathrm{WEN}^{1^{*}}$, Wen MEI ${ }^{2}$ \\ ${ }^{1}$ School of Landscape Architecture, Zhejiang Agriculture and Forest University, Hangzhou, \\ Zhejiang Province, PR of China \\ ${ }^{2}$ Suzhou World Cultural Heritage Classical Garden Protection and Supervision Center, \\ Suzhou, Jiangsu Province, PR of China
}

Received 05 April 2020; accepted 13 October 2020

\begin{abstract}
Highlights
This article refines monitoring indicators and evaluation standards for garden heritage ontologies.

Quantifies monitoring data of garden heritage ontologies.

Specifies early-warning gradation which can exhibit further damage level for garden heritage.

Constructs garden heritage monitoring and early-warning grading model based on fuzzy cluster analysis.

$>$ Obtains early-warning gradation results for architecture, ancient tree, rock, water and furnishing heritage.

Spatial distribution map of early-warning grade was obtained.
\end{abstract}

\begin{abstract}
Taking garden heritage ontologies as the object, this paper explores monitoring and early-warning methods of heritage based on fuzzy cluster analysis. A monitoring and early-warning system for garden heritage ontologies is designed and consists of monitoring indexes, a monitoring program, monitoring data collection, application of an early-warning grading evaluation model and conclusion of early-warning grading. Taking the Suzhou classical garden heritage as an example, it can be concluded that the systematic method can integrate various qualitative and quantitative index values and collectively reflect the overall state of garden heritage ontologies as well as match a heritage monitoring ontology with an early warning grade by calculating the data similarity matrix, membership matrix, fuzzy similarity matrix, fuzzy equivalent matrix and cut matrix. Five kinds of heritage ontologies with a total of twenty-seven heritage monitoring indicators are applied in the model and then be matched with MATLAB software to obtain accurate early-warning results. When types of heritage ontology need to be expanded, the heritage is further refined, or the heritage is more comprehensive, this method is applicable.
\end{abstract}

Keywords: garden heritage, monitoring and early warning, Suzhou classical garden, early-warning gradation, systematic method.

\section{Introduction}

Garden heritage refers to the natural and cultural heritage that is strongly related to the construction and aesthetic activities of the landscape, including natural and cultural heritage sites that have been registered in national and world heritage lists, and the tangible heritage protected by law but not yet registered on the heritage lists, such as traditional gardens, cultural landscapes, and scenic spots (Li \& Yuan, 2014). From the Athens Charter (Congrès International d'Architecture Modern [CIAM], 1933) and the Venice Charter (International Council of Monuments and Sites [ICOMOS], 1964) to the Convention Concerning the Protection of the World Cultural and Natural Heritage (United Nations Educational, Scientific and Cultural Organisation [UNESCO], 1972), the protection of garden heritage has gone through the process of ideological beginning, protection principles and consensus formation. The Charter of the International Council on Monuments and Sites adopted in Moscow (ICOMOS, 1978) explicitly defined valuable historical parks as heritage sites under

*Corresponding author. E-mail: wenrk@zafu.edu.cn 
protection for the first time. The Florence Charter (ICOMOS \& International Federation of Library Associations [IFLA], 1981) clearly defined the concept of a historical garden.

In 1992, the concept of cultural garden heritage was proposed (UNESCO World Heritage Centre, 1992). The Operational Guidelines for the Implementation of World Heritage Convention (UNESCO World Heritage Centre, 1992) identified park landscapes as landscapes intentionally designed and built by humans and stated that they are often (but not always) related to religion or other monuments or groups of buildings. As one theme of cultural garden heritage, garden heritage is an important part of cultural garden heritage. At present, there are 27 world heritage sites with a garden theme (Wu et al., 2016). China has 5 of these sites. They are the Chengde Mountain Resort (1994), Suzhou Classical Gardens (1997, 2000), Summer Palace (1998), Beijing Royal Altars-Temple of Heaven (1998) and Hangzhou West Lake (2011) (Li \& Yuan, 2014; Wu et al., 2016). In addition to world heritage sites, China also has a kind of garden heritage with cultural relics protection. At present, the list consists of 537 garden heritage sites (Wu et al., 2016). The principles for conservation of heritage sites in China states that cultural landscape is a kind of cultural relic and historic site with living characteristics, and it is in a process of constant change. Suzhou Classical Gardens have become weak and vulnerable as time has gone by. Improper use and erosion by natural forces often cause accidental damage to the garden. Therefore, using scientific methods to explore the classical garden heritage monitoring and early-warning system is an important component of current heritage conservation research (Feilden \& Jokilehto, 2008).

The UNESCO World Heritage List contains more than 1,000 cultural, natural and mixed heritage sites, many of which are threatened today (Cigna et al., 2018). Levin pointed out that 54 UNESCO World Heritage Sites are in danger, of which $40 \%$ are in the Middle East (Levin et al., 2019). To reduce the risk of conflict, preventive protection is an effective method for heritage site protection (Eken et al., 2019). UNESCO has proposed to carry out world heritage monitoring for 20 years, and requires monitoring sites to provide monitoring reports every 6 years (Zhou, 2015). In 2002, the United Kingdom introduced the Draft Indicators for World Heritage Monitoring (Zhang, 2011). In 2009, UNESCO proposed the concept of risk management for cultural heritage monitoring (Song, 2013). A risk assessment system for cultural heritage protection in Italy began (Arborea et al., 2014). Both Canadian and British heritage management agencies have introduced advanced technologies to monitoring (Kiriama et al., 2010) and evaluated the collected monitoring data (Madole, 2014). Wu combined the cases of the Suzhou Tiger Hill Pagoda, the main hall of Baoguo Temple, and the Winding Brook Chamber of Lingering Garden to find solutions to heritage problems from the perspective of monitoring and maintenance (Wu, 2011).
Zhang pointed out difficulties and significant features in monitoring heritage sites in China (Zhang, 2012). Zhu conducted research into monitoring technologies (Zhu et al., 2010). Jiang focused on dynamic monitoring theory, indicators, and technologies based on RS, GIS and GPS technology (Jiang, 2010).

The early warning of garden heritage protection is to analyze and evaluate the garden heritage and its external space status in a certain period, then forecast, determine the space condition and change trend, speed, etc., forecast the space-time scope and danger degree of abnormal conditions, and put forward warning information and corresponding preventive measures according to the specific situation of abnormal changes (Yang et al., 2015). Early warning is the ultimate goal for monitoring. Early warning in the field of cultural heritage did not officially become a responsibility of the UNESCO World Heritage Centre until 1994. Bahraminejad proposed an early warning system and optimization method that can make up for deficiencies in protection and management of heritage sites (Bahraminejad et al., 2018). Leng studied the protection of historical villages based on the fuzzy analytic network process (F-ANP) (Leng, 2011). Wei studied ancient trees in the Humble Administrator's Garden in Suzhou and proposed early warning levels and protection measures for ancient trees (Wei et al., 2010). Yang proposed the object, content, method and effect of early warnings for garden heritage sites (Yang et al., 2015).

In summary, the international conventions and heritage protection charters indicate the recognition of garden heritage protection and put forward the basis and guidelines for garden heritage protection. Many studies have revealed techniques, monitoring and early-warning methods for garden heritage protection. However, there have been too many qualitative discussions in the past, and quantitative studies are still lacking. Compare to community participation in cultural heritage management ( $\mathrm{Li}$ et al., 2020) research in this paper concerned government-led monitoring and applied a new method to work with monitoring data in which comprise five heritage ontologies, four criteria and 27 indicators. Not only analyzing species diversity (Cheryl et al., 2018), assessing the heritage value of scenic, natural and cultural (Carolina et al., 2018), it focused on architectural heritage, ancient tree heritage, rock heritage, water heritage and furnishing heritage, pursued improvement of heritage management in accordance with monitoring and early-warning results obtained. The research revealed that active participant (Hotimah et al., 2015), especially monitoring heritage becomes absolutely necessary to preserve garden heritage ontologies. Different from regarding BIM as a resource in heritage management (Godinho et al., 2019), this work applied Matlab software and implement more matrix calculation to achieve a manageable model as a useful decision support tool within the heritage management framework. The method and practice can develop the policy networks (Zhao et al., 2020) of garden heritage protection management. 


\section{Method}

Based on monitoring of the Suzhou Classical Garden heritage ontologies, this paper proposes a monitoring and early-warning indicator system and evaluation criteria for garden heritage ontologies and then carries out early warning grading in the Suzhou Classical Garden using fuzzy cluster analysis (Wen \& Ding, 2001).

\subsection{Indicators and weights for monitoring and early warning of garden heritage}

According to differences in building appearance, building structure, and building decoration, there are 11 monitoring indicators related to buildings, such as vertical settlement, column inclination, deflection of beam, and building displacement. Monitoring indicators of garden rocks focus on safety and affected factors. The indicators include plant influence, water influence, human influence, and security and stability of the rocks. Monitoring indicators for ancient trees include growth situation, site environment, trauma symptoms, and the degree of damage. Water monitoring indicators include changes in water form and quality. Monitoring indicators for furnishings are divided into 5 categories according to furnishings and management. All indicators are shown in Figure 1.

Aided by MATLAB software, the AHP method was used to determine weights for early warning evaluation based on monitoring indicators of garden heritage ontologies and passed the consistency test. According to saaty 1-9 scale method, the measurement scale was divided into nine levels, among which 1, 3, 5, 7, 9 correspond to equally important, slightly important, relatively important, very important and absolutely important, while 2, 4, 6, 8 is between two adjacent states. Combined with hierarchical structure of indicators, along with scores from experts in a meeting, the judgment matrix of relative importance for indicators in five heritage ontologies are obtained, as shown in Tables A1-A5 of Appendix. All weights are shown in Table A6 of Appendix.

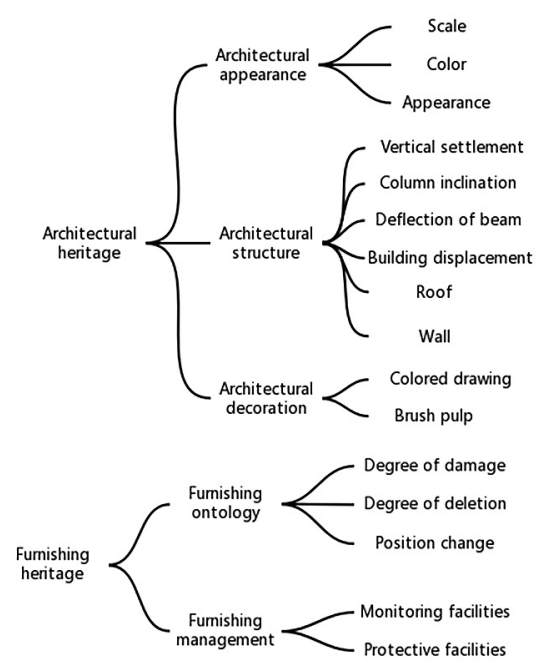

\subsection{Early-warning evaluation standards for garden heritage ontologies}

The evaluation standard is the criterion for evaluating the damage to heritage ontologies. The early-warning grades for garden heritage are divided into normal, first level, second level and third level. The corresponding evaluation score is from 1 to 4 points. The early-warning evaluation standards for garden architecture heritage are shown in Table A7 of Appendix.

\subsection{Garden heritage early-warning grading model based on fuzzy cluster analysis}

Fuzzy clustering analysis methods (Fuzzy C-Means Algorithm) are suitable for robust analysis of non-precise data, especially subjective data (Ferraro \& Giordani, 2017). It was used to investigate the sustainability of renewable energy (Wang \& Yang, 2020), integrate cooperative game data envelopment analysis model with application in hospital efficiency (Omrani et al., 2018) as well as online control indoor environment's safety and health (Cao et al., 2020). Since garden heritage monitoring and early warning evaluation are relate to many subjective indicators, the grading model can derive from this method. Articles in Fuzzy Sets and Systems journalist show more detail processing, formula and matrixes (Saha \& Das, 2018). Main steps of fuzzy clustering analysis comprise similarity matrix, membership matrix, fuzzy similarity matrix, fuzzy equivalent matrix, $\lambda$-cut matrix construction and so on (Wen \& Ding, 2001).

The model integrates various qualitative and quantitative monitoring values and collectively reflect the overall state of heritage ontologies. First, through initial quantification of the data, the model puts all qualitative and quantitative indicators of heritage monitoring objects together for data analysis. Second, it matches a heritage monitoring object with an early warning grade through calculation of the data similarity matrix, membership matrix, fuzzy similarity matrix, fuzzy equivalent matrix and cut matrix. It classifies the early warning level of heritage monitoring objects.

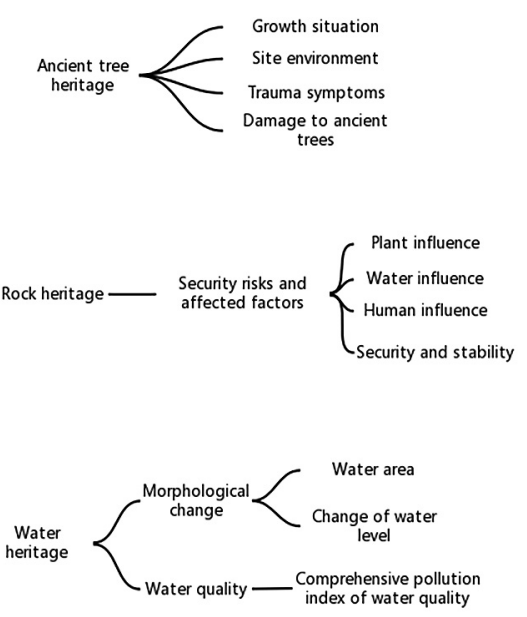

Figure 1. Monitoring indexes of garden heritage 


\subsection{Monitoring and data collection}

Heritage monitoring uses a combination of on-site inspection, visual inspection, and instrument monitoring. The monitoring work is divided into two sub-items: daily monitoring and deformation monitoring (Bai et al., 2013). Daily monitoring relies on patrol and visual inspections. Monitoring content includes the peeling, pollution, and fading of paint on walls, columns, beams, doors, windows and guardrails. Other items include whether the roof, doors and windows are damaged or rotten, whether there are cracks or leaks on the roof, whether the tiles and ridge are intact, whether there are weeds on the roof and so on. Finally, one monitors whether the wall is deformed, inclined, weathered, or soaked and whether the surface of brush slurry has fallen off or is moldy or discolored.

Deformation monitoring includes monitoring the vertical settlement, horizontal displacement, column inclination,

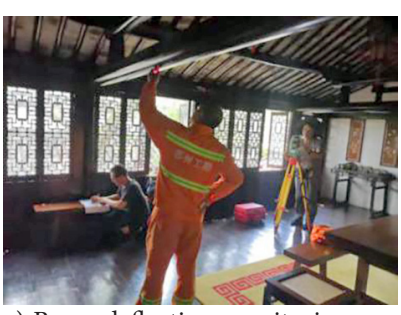

a) Beam deflection monitoring

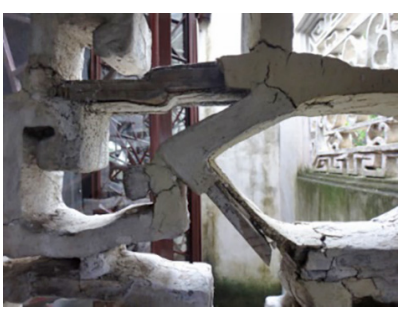

c) Damage to the wall and leaking windows

Figure 2. Building Structural Monitoring and beam deflection. It must be carried out strictly in accordance with the Code for Measurement of Building Deformation. Vertical settlement monitoring uses precise level measurement methods, and settlement monitoring points are placed under the pillars of each building. The adjustment control software Nasew V3.0 (Sunwaysurvey, Beijing, China) of the engineering control network was used to carry out rigorous adjustment calculations, and the elevation values for each settlement monitoring point were obtained. Vertical settlement of monitoring points is the difference between this monitored elevation value and the last monitored elevation value. Horizontal displacement monitoring is performed by the total station polar coordinate method; several monitoring points are arranged on each building, and each monitoring point is arranged on a column. Column tilt monitoring is monitored by using a hanging plumb line, and the amount of architectural tilt can be determined based on its deviation value. Deflection is the bending value of a garden building and its components in a horizontal or vertical direction. Beam deflection monitoring uses a total station to directly measure the elevation of each nail root and takes the difference between average elevations of two ends and elevation at the middle. Figure 2 shows beam deflection, horizontal displacement monitoring, and damage to the wall and leaking windows.

\subsection{Systematic method of garden heritage monitoring and early warning}

Indicators of heritage ontology at garden heritage sites are monitored. Combined with monitoring data, based on early-warning evaluation standards and index weights, and quantified and standardized monitoring data, the early-warning grading evaluation model was applied and MATLAB software was used for calculations, leading to a systematic method of garden heritage monitoring and early warning, as shown in Figure 3.

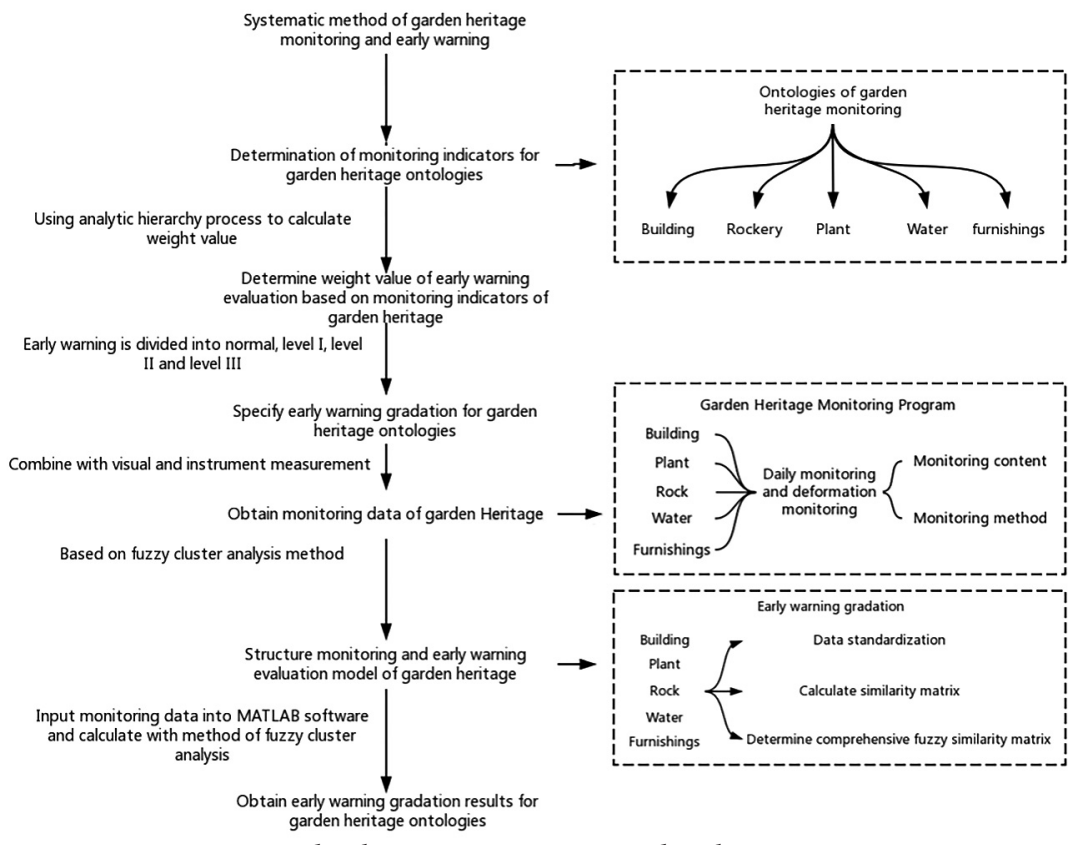

Figure 3. Garden heritage monitoring and early warning system 
The garden heritage monitoring and early-warning system involves five kinds of heritage ontology, for a total of twenty-seven heritage monitoring indicators. Considering the large number of monitoring objects at a heritage site and the monitoring results for many years, a large amount of monitoring data is available. These data can be fully combined with the heritage monitoring and early-warning system, undergo scientific analysis, and then be matched with MATLAB software, to obtain accurate early-warning results.

\section{Results and discussions}

\subsection{Garden architecture}

\subsubsection{Monitoring results}

Five representative buildings (the Cloud-crowned Peak, the Hanbi Mountain Villa, the Pellucid Building, the Donglai Cottage, the Sishi Hall) among 20 architectural heritage sites of the Lingering Garden and Garden of Cultivation were taken as examples. Quantitative data, including vertical settlement, horizontal displacement, column tilt and beam deflection, were monitored. The qualitative monitoring data are the latest data from building monitoring. Data in Table 1, Table 2, Table 3 and Table 4 were obtained in August 2018 and reflect the monitoring records of vertical settlement, horizontal displacement, and beam deflection at the Cloud-crowned Peak in the Lingering
Garden. Table A8 (in Appendix) shows the raw data for all monitoring indicators for five buildings.

Table 1. Settlement monitoring record of the Cloud-Capped Building in the Lingering Garden

\begin{tabular}{|l|c|c|c|c|}
\hline $\begin{array}{c}\text { Column } \\
\text { number }\end{array}$ & $\begin{array}{c}\text { Last } \\
\text { elevation } \\
(\mathrm{mm})\end{array}$ & $\begin{array}{c}\text { Current } \\
\text { elevation } \\
(\mathrm{mm})\end{array}$ & $\begin{array}{c}\text { Settlement } \\
\text { amount } \\
(\mathrm{mm})\end{array}$ & $\begin{array}{c}\text { Settlement } \\
\text { rate }(\mathrm{mm} / \mathrm{d})\end{array}$ \\
\hline $\begin{array}{l}\text { Column } \\
\text { number } 1\end{array}$ & 2398.82 & 2400.27 & 1.45 & 0.0020 \\
\hline$\ldots$ & $\ldots$ & $\ldots$ & $\ldots$ & $\ldots$ \\
\hline $\begin{array}{l}\text { Column } \\
\text { number 7 }\end{array}$ & 2422.71 & 2425.44 & 2.73 & 0.0038 \\
\hline$\ldots$ & $\ldots$ & $\ldots$ & $\ldots$ & $\ldots$ \\
\hline $\begin{array}{l}\text { Column } \\
\text { number 13 }\end{array}$ & 2423.66 & 2425.24 & 1.58 & 0.0022 \\
\hline \multicolumn{5}{|c|}{ Maximum settlement rate: $0.0038 \mathrm{~mm} / \mathrm{d}$} \\
\hline
\end{tabular}

\subsubsection{Quantification of qualitative monitoring data}

Many indicators in garden heritage monitoring are qualitative. For example, the scale, color, shape, roof, wall, painting of garden architecture and all rockery, plants and furnishings monitoring indicators are qualitative indicators. A qualitative index can be quantified by the early warning evaluation standard. First, one assigns different grades to the early warning of the heritage ontology (as

Table 2. Displacement monitoring record of the Cloud-Capped Building in the Lingering Garden

\begin{tabular}{|c|c|c|c|c|c|c|c|}
\hline \multirow{2}{*}{$\begin{array}{c}\text { Monitoring } \\
\text { point }\end{array}$} & Last coordinate value $(\mathrm{mm})$ & Current coordinate value $(\mathrm{mm})$ & Deformation value $(\mathrm{mm})$ & \multirow{2}{*}{ Tools used } \\
\cline { 2 - 8 } & $\mathrm{X}$ & $\mathrm{Y}$ & $\mathrm{X}$ & $\mathrm{Y}$ & $\Delta \mathrm{X}$ & $\Delta \mathrm{Y}$ & 3 \\
\hline A (column 1) & 45194045 & 51240052 & 45194048 & 51240055 & 3 & 4 & Total station TS30, \\
\hline B (column 7) & 45198284 & 51251360 & 45198279 & 51251364 & -5 & 4 Maximum displacement: $5 \mathrm{~mm}$ \\
\hline
\end{tabular}

Table 3. Tilt monitoring record of the Cloud-Capped Building in the Lingering Garden

\begin{tabular}{|c|c|c|c|c|c|c|c|c|c|}
\hline \multirow{2}{*}{ Column number } & \multicolumn{4}{|c|}{ Last measurement data $(\mathrm{mm})$} & \multicolumn{4}{|c|}{ Current measurement data $(\mathrm{mm})$} & \multirow{2}{*}{ Conclusion $(\mathrm{mm})$} \\
\hline & east & west & south & north & east & west & south & north & \\
\hline Column number 2 & & 20 & 8 & & & 30 & 28 & & 10 to west, 20 to south \\
\hline Column number 6 & & 30 & 32 & & & 35 & 55 & & 5 to west, 23 to south \\
\hline$\ldots$ & & $\ldots$ & $\ldots$ & & & $\ldots$ & $\ldots$ & & $\ldots$ \\
\hline Column number 13 & 12 & & 45 & & 13 & & 50 & & 1 to east, 5 to south \\
\hline
\end{tabular}

Table 4. Deflection monitoring record of the Cloud-Capped Building in the Lingering Garden

\begin{tabular}{|l|c|c|c|c|}
\hline \multicolumn{1}{|c|}{ Number of bearing beam } & $\begin{array}{c}\text { Length of bearing } \\
\text { beam }(\mathrm{mm})\end{array}$ & $\begin{array}{c}\text { Last measurement } \\
(\mathrm{mm})\end{array}$ & $\begin{array}{c}\text { Current measurement } \\
(\mathrm{mm})\end{array}$ & $\begin{array}{c}\text { Change value } \\
(\mathrm{mm})\end{array}$ \\
\hline Numbers 4-13 & 4400 & 10 & -10 & -20 \\
\hline Numbers 1-10 & 4400 & 3 & 9 \\
\hline \multicolumn{2}{|c|}{ Maximum deflection of beam: $20 \mathrm{~mm}$} \\
\hline
\end{tabular}

Note: “+” is downward, “-” is upward. 
shown in Table A7 of the Appendix). Second, one compares monitoring results of the heritage ontology with the early-warning grade evaluation standards and scores them. For example, after initial quantification of monitoring data in Table A8, Table A9 (in Appendix) is obtained.

\subsubsection{Early warning results}

Based on the monitoring data, the early-warning evaluation method for heritage was applied and analyzed by MATLAB software, and the early-warning grades of five buildings were obtained, as shown in Table 5.

Table 5. Early warning grade for architecture in the Lingering Garden and Garden of Cultivation

\begin{tabular}{|l|l|l|}
\hline Early-warning grade & \multicolumn{1}{|c|}{ Name } & \multicolumn{1}{c|}{ Location } \\
\hline Normal & $\begin{array}{l}\text { The Donglai Cottage; } \\
\text { The Sishi Hall }\end{array}$ & $\begin{array}{l}\text { Garden of } \\
\text { Cultivation }\end{array}$ \\
\hline First level & $\begin{array}{l}\text { The Hanbi Mountain } \\
\text { Villa }\end{array}$ & $\begin{array}{l}\text { Lingering } \\
\text { Garden }\end{array}$ \\
\hline Second level & $\begin{array}{l}\text { The Cloud-Capped } \\
\text { Building }\end{array}$ & $\begin{array}{l}\text { Lingering } \\
\text { Garden }\end{array}$ \\
\hline Third level & The Pellucid Building & $\begin{array}{l}\text { Lingering } \\
\text { Garden }\end{array}$ \\
\hline
\end{tabular}

Taking all garden architecture in the Lingering Garden and Garden of Cultivation as the object, a spatial distribution map of early-warning grade was obtained, as shown in Figure 4 and Figure 5.

For the evaluation of early warning grade of architectural heritage, it is necessary to subdivide the monitoring index system and select the most critical indicators, the disease types of the architectural heritage shall be investigated before the assessment, the existing structural problems and natural environmental impact factors shall be diagnosed to avoid over monitoring (Mesquita et al., 2018). The main information collection methods of digital monitoring of architectural heritage include traditional measurement technology, Photogrammetric technology and 3D laser scanning technology (Zhou, 2018). Traditional measurement technology from data acquisition to analysis has to go through manual processing. Photogrammetric technology has a wider range of data collection, and also makes the work efficiency significantly improved. 3D laser scanning technology is mainly used in the monitoring of the surface damage and geometric deformation of architectural heritage (Campiani et al., 2019). A monitoring and management system of architectural heritage based on the data results of digital technology was summarized, but did not make a study on the early warning of architectural heritage (Gao, 2018). A finite element software ANSYS can also be used to proposed the damage early warning mechanism applicable to traditional wood structure (Meng, 2018).

\subsection{Rock heritage}

Taking all garden rocks in the Lingering Garden, Garden of Cultivation, Humble Administrator's Garden and Lion Forest Garden as objects, the results of early-warning grade evaluation of rocks were obtained, as shown in Table 6.

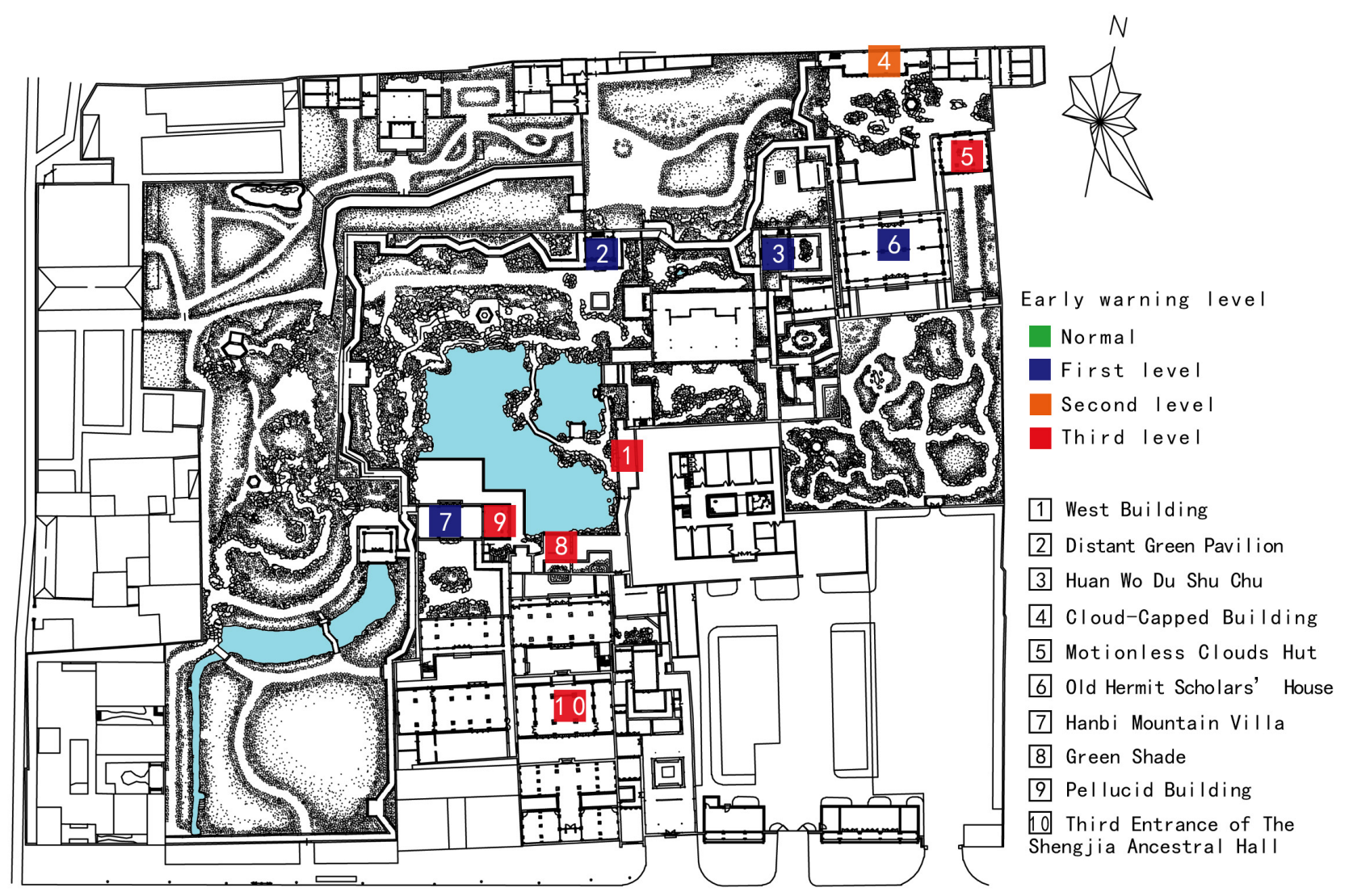

Figure 4. Early warning level of garden architecture heritage in the Lingering Garden 


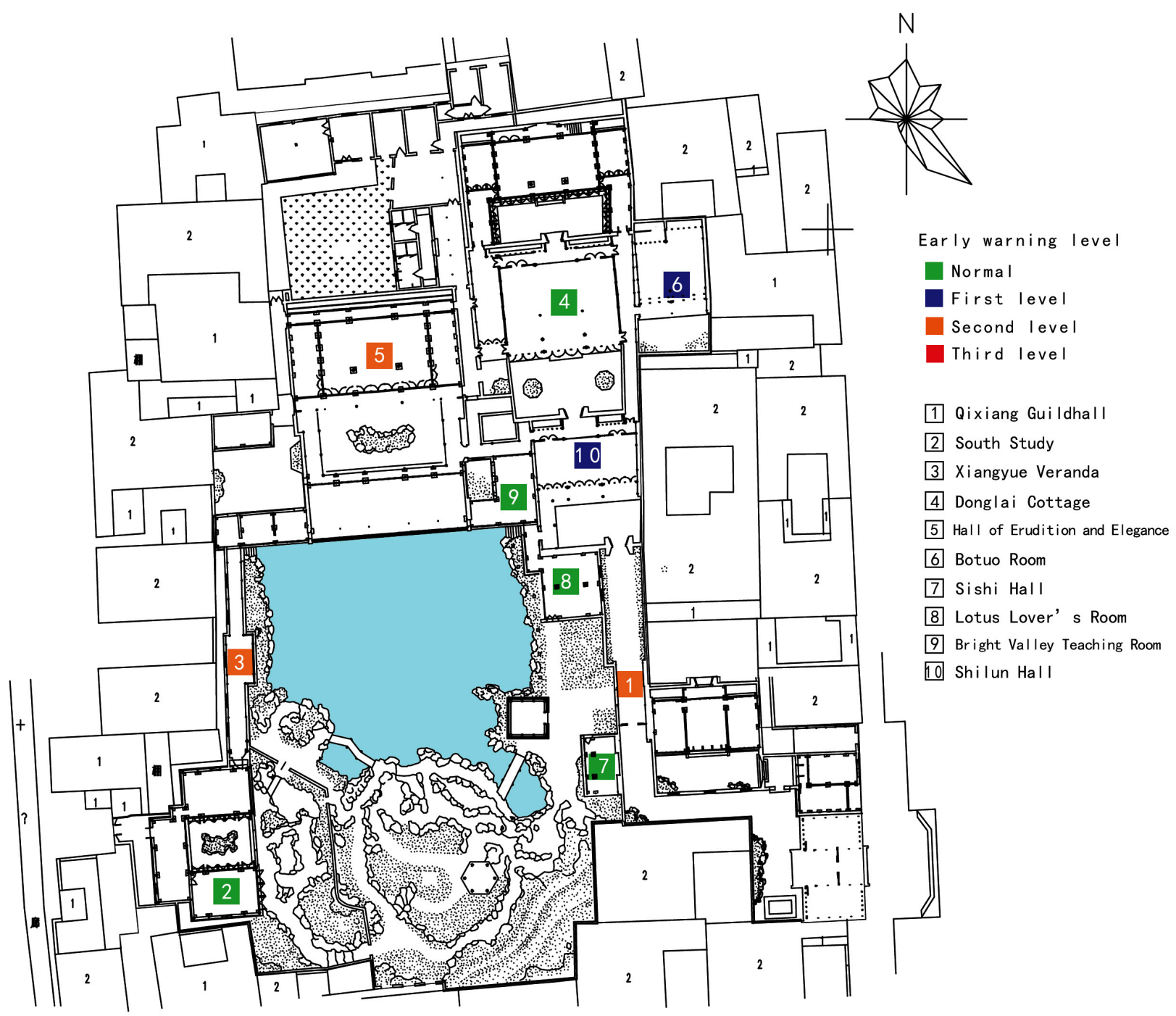

Figure 5. Early warning level of garden architecture heritage in the Garden of Cultivation

Table 6. Early-warning grade for rocks in the Lingering Garden, Garden of Cultivation, Humble Administrator's Garden and Lion Forest Garden

\begin{tabular}{|l|l|l|}
\hline $\begin{array}{c}\text { Early warning } \\
\text { grade }\end{array}$ & \multicolumn{1}{|c|}{ Name } & \multicolumn{1}{c|}{ Location } \\
\hline Normal & Canglin Stone & Lingering Garden \\
\hline First level & $\begin{array}{l}\text { Cloud Capped } \\
\text { Peak }\end{array}$ & Lingering Garden \\
\hline Second level & $\begin{array}{l}\text { Qingyao Island } \\
\text { (north) }\end{array}$ & Garden of Cultivation \\
\hline Second level & $\begin{array}{l}\text { Lion Rolling } \\
\text { Hydrangea }\end{array}$ & Lion Forest Garden \\
\hline Third level & Water Shore Rock & $\begin{array}{l}\text { Humble } \\
\text { Administrator's Garden }\end{array}$ \\
\hline Third level & Duanxia Peak & Lingering Garden \\
\hline Third level & Rockery Hills & Lingering Garden \\
\hline
\end{tabular}

The shape of rock heritage is irregular, so it is difficult to measure it accurately by traditional measurement methods. A photogrammetry with lidar technology was proposed a digital measurement method for rockery heritage
(Zhang et al., 2018). UAV aerial camera and photogrammetry technology were also used to measure the rock heritage and compared the accuracy of the two technologies (Gu et al., 2016). Further, digital photogrammetry, lidar scanning and point cloud visualization technology were applied to collect spatial information of rockery and build a digital 3D model (Yang \& Han, 2018). The appliance of new measurement technology makes it possible for the dynamic monitoring of the rock heritage. Comparing the data in different periods, it can be quickly and accurately identified the changes of elements for rockery heritage.

\subsection{Ancient tree heritage}

The archive of ancient trees in the Lingering Garden and Garden of Cultivation are shown in Table A10 of Appendix. Among them, No. 002\# and 003\# Ginkgo biloba Linn. was obviously tilted (Figure 6), and the growth of Platycladus orientalis (Linn.) and Podocarpus macrophyllus (Thunb.) Sweet was weak.

Taking all ancient trees in the Lingering Garden and Garden of Cultivation as objects, the results of the 

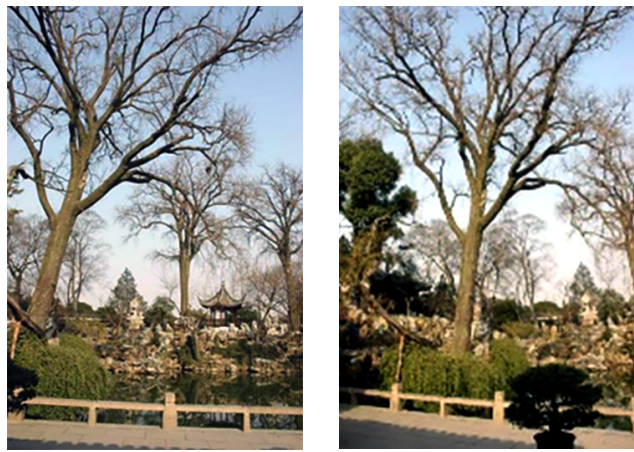

Figure 6. The Ginkgo biloba Linn. obliquity is obvious in the middle of the Lingering Garden

early-warning grade evaluation of ancient trees were obtained, as shown in Table 7.

As time has gone by, the adaptability of ancient trees to environmental changes is gradually weakened, and the aging phenomenon is serious. Beside artificial on-site measurement and document recording, nondestructive testing technology, ultrasonic stress wave testing ( $\mathrm{Du}, 2015)$, GPR testing (Gan, 2016) and micro drill resistance testing (Shi et al., 2017) were mostly used to obtain the data of tree diseases. For example, in Yangzhou Slender West Lake scenic spot, 157 ancient trees were evaluated for health by using non-destructive monitoring technology, $88.59 \%$ of them are in good health, and some of them are seriously decayed. On the other hand, mathematical morphology and skeleton extraction algorithm were used to finish the thin line processing of trunk image, so as to calculate the inclination angle of trunk (Jin, 2018). A real-time monitoring micro-environment based on Internet technology was conducted (Yin, 2016) which can help to avoid environmental effect to ancient trees.

Table 7. Early-warning grade of ancient trees in the Lingering Garden and Garden of Cultivation

\begin{tabular}{|l|l|l|}
\hline $\begin{array}{l}\text { Early warning } \\
\text { level }\end{array}$ & \multicolumn{1}{|c|}{ Name } & \multicolumn{1}{|c|}{ Location } \\
\hline Normal & $\begin{array}{l}\text { No. 019\# Magnolia grandiflora } \\
\text { Linn. }\end{array}$ & $\begin{array}{l}\text { Lingering } \\
\text { Garden }\end{array}$ \\
\hline First level & $\begin{array}{l}\text { No. 018\# Lagerstroemia } \\
\text { subcostata Koehne }\end{array}$ & $\begin{array}{l}\text { Lingering } \\
\text { Garden }\end{array}$ \\
\hline Second level & $\begin{array}{l}\text { No. 016\# Platycladus orientalis } \\
\text { (Linn.) Franco }\end{array}$ & $\begin{array}{l}\text { Lingering } \\
\text { Garden }\end{array}$ \\
\hline Second level & $\begin{array}{l}\text { No. 012\# Podocarpus } \\
\text { macrophyllus (Thunb.) Sweet }\end{array}$ & $\begin{array}{l}\text { Lingering } \\
\text { Garden }\end{array}$ \\
\hline Third level & No. 003\# Ginkgo biloba Linn. & $\begin{array}{l}\text { Lingering } \\
\text { Garden }\end{array}$ \\
\hline Third level & No. 002\# Ginkgo biloba Linn. & $\begin{array}{l}\text { Lingering } \\
\text { Garden }\end{array}$ \\
\hline Third level & $\begin{array}{l}\text { No. 003\# Hovenia acerba } \\
\text { Lindl. }\end{array}$ & $\begin{array}{l}\text { Garden of } \\
\text { Cultivation }\end{array}$ \\
\hline
\end{tabular}

\subsection{Water heritage}

Water quality monitoring is mainly to monitor each sub item (BOD5, $\mathrm{pH}$ value, ammonia nitrogen, permanganate index, chroma, transparency, total phosphorus and water temperature) of comprehensive water quality pollution index through the monitor (Yuan, 2016). The June 2019 water quality monitoring report of the Suzhou Classic Garden heritage is shown in Table A11 of Appendix. The formula for comprehensive pollution index of water quality is:

$$
P=\sum_{i=1}^{n} W_{i} \frac{C_{i}}{S_{i}}
$$

of which, $P$ is the comprehensive pollution index of water quality, $W_{i}$ is weight of monitoring project, is overstandard score, and $S_{i}$ is standard score. The standard score is determined using the Water Environment Quality Standard (GB3838-2002, China). Table A12 (in Appendix) is the initial quantification table for water monitoring data. All monitoring data can be quantified and combined with existing quantitative data for data standardization and then the fuzzy cluster analysis model is applied.

Taking water bodies in the Lingering Garden, Garden of Cultivation, Gentle Waves Pavilion, Master-of-Nets Garden and Lion Forest Garden as the objects, the results for the early-warning grade evaluation for water bodies were obtained, as shown in Table 8.

Table 8. Early-warning grade for water in the Suzhou Classical Garden

\begin{tabular}{|l|l|}
\hline $\begin{array}{c}\text { Early warning } \\
\text { grade }\end{array}$ & \multicolumn{1}{c|}{ Water bodies and locations } \\
\hline Normal & Central pond in Garden of Cultivation \\
\hline Normal & Central pool in Lingering Garden \\
\hline Normal & Internal pool in Gentle Waves Pavilion \\
\hline First level & Rosy clouds pool in Master-of-Nets Garden \\
\hline First level & Huanyun billabong, east of Lingering Garden \\
\hline Second level & Western stream of Lingering Garden \\
\hline Third level & Mid-lake Pavilion of Lion Forest Garden \\
\hline
\end{tabular}

Although the measurement is accurate, only discrete sample point data was acquired, and the change rule of large-scale water monitoring data cannot be obtained. This status will be improved by remote sensing technology (Sagan et al., 2020) and large-scale water monitoring data (Chawla et al., 2020; Wang et al., 2020). For the evaluation of water areas with special pollutant types, the single-factor index evaluation method has the problem that the single-factor influence is too large, and the objectivity of the evaluation results cannot be guaranteed (Zhu, 2019). While the method used in the paper produced high accurate and practicable results, which can effectively reduce the impact of single factor on the early-warning results. 


\subsection{Furnishings heritage}

Taking furnishings in the Lingering Garden and Garden of Cultivation as the objects, the results of early-warning grade evaluation of furnishings were obtained, as shown in Table 9.

Table 9. Early-warning grade of furnishings in the Suzhou Classical Garden

\begin{tabular}{|l|l|l|}
\hline $\begin{array}{c}\text { Early-warning } \\
\text { grade }\end{array}$ & \multicolumn{1}{|c|}{ Category } & \multicolumn{1}{|c|}{ Location } \\
\hline Normal & $\begin{array}{l}\text { Furniture in Enchanted } \\
\text { Hall of Five Peaks }\end{array}$ & Lingering Garden \\
\hline First level & $\begin{array}{l}\text { Calligraphy and painting } \\
\text { hanging in Donglai } \\
\text { Cottage }\end{array}$ & $\begin{array}{l}\text { Garden of } \\
\text { Cultivation }\end{array}$ \\
\hline First level & Corridor lantern & Lingering Garden \\
\hline Second level & $\begin{array}{l}\text { Two Kings Stickers } \\
\text { Stone }\end{array}$ & Lingering Garden \\
\hline Third level & Hall furnishings & $\begin{array}{l}\text { Garden of } \\
\text { Cultivation }\end{array}$ \\
\hline Third level & Miss Building & $\begin{array}{l}\text { Garden of } \\
\text { Cultivation }\end{array}$ \\
\hline
\end{tabular}

A computer technology was used to monitor outdoor furnishings in real time, and collected surface image information (Lin, 2016). Through the parameter evaluation system of K-means clustering algorithm, the monitoring indicators of indoor furnishings can be divided into three levels: excellent, good and substandard (Guo et al., 2019). Furnishings heritage indicators in WGRFM model include 4 secondary indicators, and 4 to 21 tertiary indicators, a total of 61 which was used to predict the displacement and fracture of outdoor furnishings heritage (Zhang, 2016). Work in this paper was applied to monitor and early warn of furnishings heritage indoors and outdoors.

\section{Practical applications and future research perspectives}

In the 1990s, the demand of "systematic monitoring of world cultural heritage" was put forward. China participated in the preparation of the second round of periodic report in 2010-2011, providing the possibility for followup data tracking and analysis (Wei, 2019). In 2015, after two rounds of periodic reports, China began to implement the annual report system of world cultural heritage monitoring, and fulfilled the monitoring obligations at the national level (Zhao, 2018). This policy not only provides a standardized module for the monitoring and early warning of world cultural heritage, but also becomes an important guiding ideology for the systematic monitoring of heritage sites.

Based on the existing monitoring system of heritage sites, this paper constructs a monitoring and early warning model for garden heritage, and applies it to practical projects. Good reference is provided to continuously monitoring of Suzhou Classical Garden and other heritage sites. At present, heritage monitoring technology is developing from traditional measurement methods to digital technology. More accurate monitoring data can be obtained by using remote sensing technology to avoid the generation of monitoring data errors ( $\mathrm{Li}, 2020)$. In construction of garden heritage monitoring and early warning, it is necessary to integrate and analyze the data. Big data technology has five advantages such as large quantity, many kinds, high value, fast speed and high precision (Gan, 2017). It can carry out data analysis across departments and regions. It is a new research direction to achieve more scientific and comprehensive management, which has great development space and application prospects (Gao et al., 2019).

According to the subordination of the evaluated objects, fuzzy cluster analysis is carried out from multiple indexes. Combining the qualitative and quantitative factors for the ontologies, the results of early warning and grading of garden heritage proposed in this study are objective. But it is necessary to use AHP method to discuss the evaluation indexes in a more detailed and hierarchical way, so as to avoid the occurrence of super fuzzy phenomenon (Cheng, 2017).

With regard to relationship between environmental factors and diseases of heritage, this paper considers that the monitoring and early warning system of garden heritage is not only limited to the garden heritage itself, but also the influencing factors of the garden heritage. The research needs to establish an environmental monitoring database to provide data for the early warning system of environmental factors (Lombardo et al., 2019), and continue to explore the impact of temperature, humidity, light, environmental pollution, passenger flow on the heritage early warning level.

Results of early warning gradation reflect the damage degree and alarm level of garden heritage, but it can't determine the most dangerous critical alarm value of heritage object. In addition to the corresponding level of early warning, the management measures of heritage protection should also be directly corresponding to the monitoring data, so as to facilitate the adoption of protection measures in case of extreme changes in a single factor and avoid the indirect obstruction of the implementation of heritage protection measures by the level of early warning. How to combine early warning gradation results of heritage with specific management measures of heritage protection and utilization is a problem that needs further discussion.

\section{Conclusions}

Early warning is the goal of monitoring. Only through early warning can the monitoring value be truly reflected. Garden heritage monitoring and early warning are an important part of garden heritage protection. After longterm heritage monitoring, combined with the garden heritage early-warning model, the damage to heritage monitoring objects is analyzed by cluster analysis and classified by early warning and management, so that monitoring 
can play a practical role. Garden heritage monitoring and early-warning systems can make heritage protection more targeted, more prompt and effective.

The early-warning classification results aimed at five types of heritage ontology. If types of heritage ontology need to be expanded, the heritage is further refined, or the heritage is more comprehensive, the systematic method is also applicable. Garden heritage monitoring and earlywarning systems can provide early warnings for heritage ontology itself, heritage single points and even heritage sites. It integrates garden heritage into heritage monitoring indicators (including index weight), index evaluation standard, early-warning grade, and so on, according to heritage site, heritage ontology, and influencing factors, and it realizes the dual goals of garden heritage monitoring and early warning under the support of powerful monitoring technology and monitoring behavior.

Garden heritage protection is a long-term systematic engineering project. With research in garden heritage monitoring and early-warning gradation, the ontologies of heritage are clustered and classified, and a large amount of accurate results from monitoring data operation is obtained. That makes it possible to monitor and early warn the garden heritage in absence of critical thresholds for heritage monitoring and early warning to avoid catastrophe, loss, and destructive events in heritage protection and management. The research can realize scientific long-term dynamic monitoring and protective early warning for garden heritage sites.

\section{Acknowledgements}

We greatly acknowledge the contribution of the Management Office of the Lingering Garden in the Suzhou Cultural Relics Bureau. They began many monitoring studies of the Suzhou Classical Garden Heritage and provided much data.

\section{References}

Arborea, A., Mossa, G., \& Cucurachi, G. (2014). Preventive fire risk assessment of Italian architectural heritage: An index based approach. Key Engineering Materials, 628, 27-33. https://doi.org/10.4028/www.scientific.net/KEM.628.27

Bahraminejad, M., Rayegani, B., Jahani, A., \& Nezami, B. (2018). Proposing an early-warning system for optimal management of protected areas (Case study: Darmiyan protected area, Eastern Iran). Journal for Nature Conservation, 46, 79-88. https://doi.org/10.1016/j.jnc.2018.08.013

Bai, C. J., Han, X., \& Wu, C. (2013). The exploration of architectural heritage deformation monitoring in the thought of preventive conservation. Journal of Xian University of Architecture \& Technology (Social Science Edition), 32(02), 54-58.

Campiani, A., Lingle, A., \& Lercari, N. (2019). Spatial analysis and heritage conservation: Leveraging 3-D data and GIS for monitoring earthen architecture. Journal of Cultural Heritage, 39, 166-176. https://doi.org/10.1016/j.culher.2019.02.011

Cao, S. J., Ding, J. W., \& Ren, C. (2020). Sensor deployment strategy using cluster analysis of Fuzzy C-Means Algorithm: Towards online control of indoor environment's safety and health. Sustainable Cities and Society, 59, 102190.

https://doi.org/10.1016/j.scs.2020.102190

Carolina, P. A., Emma, P. C., Luis, H. C., \& Eduard, A. (2018). Assessment of scenic, natural and cultural heritage for sustainable management of tourist beaches. A case study of Gran Canaria island (Spain). Land Use Policy, 72, 35-45.

https://doi.org/10.1016/j.landusepol.2017.12.030

Chawla, I., Karthikeyan, L., \& Mishra, A. K. (2020). Review of remote sensing applications for water security: Quantity, quality, and extremes. Journal of Hydrology, 585, 124826. https://doi.org/10.1016/j.jhydrol.2020.124826

Cheng, Z. Q. (2017). Design of government investment project management information system based on FCA dynamic feedback model. Tianjin University.

Cheryl Nath, D., Aravajy, S., Razasekaran, D., \& Muthusankar, G. (2018). Heritage conservation and environmental threats at the 192-year-old botanical garden in Pondicherry, India. Urban Forestry \& Urban Greening, 31, 241-251. https://doi.org/10.1016/j.ufug.2018.02.004

Cigna, F., Tapete, D., \& Lee, K. (2018). Geological hazards in the UNESCO World heritage sites of the UK: From the global to the local scale perspective. Earth-Science Reviews, 176, 166194. https://doi.org/10.1016/j.earscirev.2017.09.016

Congrès International d'Architecture Modern. (1933). Athens Charter. Trans J. Tyrwhitt. Paris, France: The Library of the Graduate School of Design, Harvard University, 1946. https://www.getty.edu/conservation/publications_resources/ research_resources/charters/charter04.html

$\mathrm{Du}, \mathrm{B}$. (2015). Study on the application of sound wave in the protection of ancient trees. Forestry of Shanxi, 6, 24-25.

Eken, E., Taşc1, B., \& Gustafsson, C. (2019). An evaluation of decision-making process on maintenance of built cultural heritage: The case of Visby. Sweden Cities, 94, 24-32. https://doi.org/10.1016/j.cities.2019.05.030

Feilden, B., \& Jokilehto, J. (2008). Guidelines for the management of world cultural heritage sites. Tongji University Press.

Ferraro, M. B., \& Giordani, P. (2017). Possibilistic and fuzzy clustering methods for robust analysis of non-precise data. International Journal of Approximate Reasoning, 88, 23-38. https://doi.org/10.1016/j.ijar.2017.05.002

Gan, M. X. (2016). Tree Radar Unit (TRU) technology detected hollow trunk and thick root distribution on the ancient and famous trees of Platycladus Orientalis in the tomb of Yellow Emperor. Northwest A\&F University.

Gan, M. Y. (2017). Research on environmental monitoring and governance based on big data. Guangxi University.

Gao, C. (2018). Research on digital monitoring method for geometric deformation of tower buildings. Beijing University of Civil Engineering and Architecture.

Gao, C., Wang, G. L., Wang, Y. M., \& Zhao, H. H. (2019). Present situation and development trend of digital monitoring technology for architectural heritage. Science of Surveying and Mapping, 44(05), 85-92.

Godinho, M., Machete, R., Ponte, M., Falcão, A. P., Gonçalves, A. B., \& Bento, R. (2019). BIM as a resource in heritage management: An application for the National Palace of Sintra, Portugal. Journal of Cultural Heritage, 43, 153-162. https://doi.org/10.1016/j.culher.2019.11.010

Gu, L. Y., Gu, X. R., \& Wusdra, J. (2016). The Application of digital 3D technology in garden surveys: Rockwork as a case study. Journal of Architecture, (S1), 35-40.

Guo, W. Q., Han, Y., Quan, D. K., Jia, J., \& Gao, W. Q. (2019). Design of environmental monitoring system for cultural relics preventive protection based on LoRa. Journal of Shaanxi University of Science \& Technology, 37(1), 140-145. 
Hotimah, O., Wirutomo, P., \& Alikodra, H. S. (2015). Conservation of world heritage botanical garden in an environmentally friendly city. Procedia Environmental Sciences, 28, 453-463. https://doi.org/10.1016/j.proenv.2015.07.055

International Council of Monuments and Sites, \& International Federation of Library Associations. (1981). The Florence Charter. Adopted by the ICOMOS at a meeting held in Florence on December 15, 1982.

International Council of Monuments and Sites. (1978). ICOMOS Statutes adopted by the Vth General Assembly in Moscow on May 22, 1978. Statutes of International Council of Monuments and Sites. https://www.icomos.org/images/DOCUMENTS/Secretariat/StatutesAmendments_R2_20130325/ st1978-statutes-en.pdf

International Council of Monuments and Site. (1964). Venice Charter. Adopted at the Second International Conference of Architects and Technicians of Historic Sites, 25-31 May 1964, Venice.

Jiang, H. (2010). Research on the methods of dynamic historic and cultural heritage based on the $3 S$ technology (pp. 1-74, 5). Tsinghua University.

Jin, C. (2018). Research and implementation of monitoring and protection system of old trees. Xidian University.

Kiriama, H., Odiaua, I., \& Sinamai, A. (2010). Impact assessment and heritage management in Africa: An overview. In H. Kiriama, I. Odiaua, \& A. Sinamai (Eds.), Cultural heritage impact assessment in Africa: An overview (pp.1-9). Centre for Heritage Development in Africa, Mombasa, Kenya.

Leng, L. (2011). The research on the early warning methods of historic towns and villages exterior space conservation. Chongqing University.

Levin, N., Ali, S., Crandall, D., \& Kark, S. (2019). World heritage in danger: Big data and remote sensing can help protect sites in conflict zones. Global Environmental Change, 55, 97-104. https://doi.org/10.1016/j.gloenvcha.2019.02.001

Li, J., Krishnamurthy, S., Pereira Roders, A., \& Wesemael, P. van. (2020). State-of-the-practice: Assessing community participation within Chinese cultural World Heritage properties. Habitat International, 96, 102107.

https://doi.org/10.1016/j.habitatint.2019.102107

Li, M., \& Yuan, L. (2014). Research on the value criteria of landscape architecture heritage. Journal of Human Settlements in West China, 29(3), 86-95.

Li, X. H. (2020). Research progress of remote sensing technology in water environment and atmospheric environment monitoring. Green Environmental Protection Building Materials, 6, $38-41$.

Lin, M. Y. (2016). Design and implementation of data monitoring system for Imperial Palace outdoor furnishings. Jilin University.

Lombardo, L., Parvis, M., Corbellini, S., Arroyave Posada, C. E., Angelini, E., \& Grassini, S. (2019). Environmental monitoring in the cultural heritage field. The European Physical Journal Plus, 134, 411. https://doi.org/10.1140/epjp/i2019-12800-2

Madole, S. (2014). International council on monuments and sites (ICOMOS) (Ethics). In C. Smith (Ed.), Encyclopedia of global archaeology. Springer.

https://doi.org/10.1007/978-1-4419-0465-2_203

Meng, Z. (2018). Research on structural health monitoring techniques of traditional timber buildings in the Yangtze River regions. Southeast University.

Mesquita, E., Arêde, A., Pinto, N., \& Antunes, P. (2018). Humberto Varum. Long-term monitoring of a damaged historic structure using a wireless sensor network. Engineering Structures, 161, 108-117.

https://doi.org/10.1016/j.engstruct.2018.02.013
Omrani, H., Shafaat, K., \& Emrouznejad, A. (2018). An integrated fuzzy clustering cooperative game data envelopment analysis model with application in hospital efficiency. Expert Systems with Applications, 114, 615-628.

https://doi.org/10.1016/j.eswa.2018.07.074

Sagan, V., Peterson, K. T., Maimaitijiang, M., Sidike, P., Sloan, J., Greeling, B. A., Maalouf, S., \& Adams, C. (2020). Monitoring inland water quality using remote sensing: potential and limitations of spectral indices, bio-optical simulations, machine learning, and cloud computing. Earth-Science Reviews, 205, 103187. https://doi.org/10.1016/j.earscirev.2020.103187

Saha, A., \& Das, S. (2018). On the unification of possibilistic fuzzy clustering: Axiomatic development and convergence analysis. Fuzzy Sets and Systems, 340, 73-90.

https://doi.org/10.1016/j.fss.2017.07.005

Shi, X. L., Wang, L. H., Xu, H. D., Xu, Q. B., Cao, S. K., \& $\mathrm{Xu}$, M. X. (2017). Quantitative characterization of decay detection in standing trees of Korean pine based on Resistograph and ERT. Journal of Beijing Forestry University (Social Sciences), 39(9), 102-111.

Song, Z. W. (2013). Seismic hazard assessment of masonry pagodas. Xi'an University of Architecture and Technology.

United Nations Educational, Scientific and Cultural Organisation. (1972). Convention concerning the protection of the world cultural and natural heritage. Adopted by the General Conference at its seventeenth session, 16 November 1972, Paris. https://whc.unesco.org/archive/convention-en.pdf

Wang, Q., \& Yang, X. (2020). Investigating the sustainability of renewable energy: An empirical analysis of European Union countries using a hybrid of projection pursuit fuzzy clustering model and accelerated genetic algorithm based on real coding. Journal of Cleaner Production, 268, 121940. https://doi.org/10.1016/j.jclepro.2020.121940

Wang, X. X., Wang, J., \& Cui, Y. H. (2020). Remote sensing monitoring on spatial differentiation of suspended sediment concentration in a River-Lake system based on sentinel-2 MSI imaging: A case for Shengjin Lake and connected Yangtze River section in Anhui province. Environmental Science, 41(3), 1207-1216. https://doi.org/10.13227/j.hjkx.201907164

Wei, Q. (2019). Viewing the development and implementation mechanism of the world heritage convention from the perspective of updates and changes in periodic reports. Study on Natural and Cultural Heritage, 4(6), 5-20.

Wei, S. L., Mao, X. W., \& Xiao, X. D. (2010). Research on monitoring and early-warning standards of ancient and famous trees protection in the Humble Administrator's Garden. Journal of Landscape Research, 16, 8569-8572.

Wen, R. K., \& Ding, L. Y. (2001). Study on the grading evaluation of modern architectural cultural value based on FCA. Sichuan Architecture, 3, 17-20.

Wu, J. Y., Pan, H., \& Du, Y. (2016). Spatial-temporal characteristics and impacting factors of historic gardens in China. $\mathrm{Hu}$ man Geography, 31(1), 50-56.

Wu, M. P. (2011). Monitoring of architectural heritage under the concept of preventive conservation. Huazhong Architecture, 29, 169-171.

Yang, C., \& Han, F. (2018). Digital heritage landscape: Research on spatial character of the grand rockery of Yuyuan Garden in Shanghai based on 3D Point Cloud technologies. Chinese Landscape Architecture, 34(11), 20-24.

Yang, J., Chen, D., \& Zhang, Q. P. (2015). Analysis of the progress of Chinese classic garden heritage protection and early warning. Urban Development Studies, 22(4), 91-97. 
Yin, X. J. (2016). The Design of ancient and famous tree environmental monitoring system based on Internet of Things. Fujian Normal University.

Yuan, L. L. (2016). Investigation on water quality of classical gardens in Suzhou. Suzhou University.

Zhang, C. Z. (2011). Monitoring the impact of cultural heritage tourism: The construction of international experience method and index system. Beijing Union University. 2011 China Tourism Research Annual Conference Proceedings of tourism journal. Beijing Union University: Editorial Department of Tourism Journal, 17.

Zhang, Q. P., Liang, H. L., \& Li, Z. W. (2018). Research of the application of digital survey techniques in private garden. Journal of Nanjing Forestry University (Natural Sciences Edition), 42, 1-5.

Zhang, X. H. (2016). Health risks assessment of open-air relics based on the internet of things. Xian University of Architecture and Technology.

Zhang, Y. C. (2012). China's world cultural heritage monitoring system. Beijing University of Chemical Technology.

Zhao, Y. (2018). Construction status and development ideas of China world cultural heritage monitoring and early warning general platform: Thinking based on demand research. China Cultural Heritage, 1, 46-50.

Zhao, Y., Ponzini, D., \& Zhang, R. (2020). The policy networks of heritage-led development in Chinese historic cities: The case of Xi'an's Big Wild Goose Pagoda area. Habitat International, 96, 102106. https://doi.org/10.1016/j.habitatint.2019.102106

Zhou, H. (2018). Study on investigation and recording methods of architectural heritage. Chongqing University.

Zhou, S. N. (2015). Thinking and research on improving the effectiveness of the world heritage monitoring: A case study of Suzhou classical gardens monitoring. Chinese Landscape Architecture, 31(11), 55-58.

Zhu, S. C. (2019). Construction and application research of Suzhou water environment monitoring management information system based on GIS: Taking Jinji Lake as an example. Suzhou University of Science and Technology.

Zhu, Y. F., Chen, H. G., Zhang, D. M., Wu, J. Q., Wu, S. L., Zhang, J. F., \& Luo, Y. (2010). Subsidence of Suzhou area from 1995 to 2000 detected by persistent scatterers for SAR interferometry technique. Advance in Earth Sciences, 25(4), 428-434.

\section{APPENDIX}

Table A1. Relative importance judgment matrix for monitoring indicators of architecture heritage

\begin{tabular}{|c|c|c|c|c|c|c|c|c|c|c|c|}
\hline $\begin{array}{l}\text { Architectural } \\
\text { heritage }\end{array}$ & Scale & Color & $\begin{array}{l}\text { Appea- } \\
\text { rance }\end{array}$ & $\begin{array}{c}\text { Vertical } \\
\text { settlement }\end{array}$ & $\begin{array}{l}\text { Column } \\
\text { inclination }\end{array}$ & $\begin{array}{l}\text { Deflection } \\
\text { of beam }\end{array}$ & $\begin{array}{c}\text { Building } \\
\text { displacement }\end{array}$ & Roof & Wall & $\begin{array}{l}\text { Color } \\
\text { drawing }\end{array}$ & $\begin{array}{l}\text { Brush } \\
\text { pulp }\end{array}$ \\
\hline Scale & 1 & 3 & 2 & $1 / 4$ & $1 / 4$ & $1 / 5$ & $1 / 3$ & 2 & $1 / 2$ & $1 / 3$ & $1 / 3$ \\
\hline Color & $1 / 3$ & 1 & $1 / 2$ & $1 / 6$ & $1 / 6$ & $1 / 7$ & $1 / 5$ & $1 / 2$ & $1 / 4$ & 1 & 1 \\
\hline Appearance & $1 / 2$ & 2 & 1 & $1 / 5$ & $1 / 5$ & $1 / 6$ & $1 / 4$ & 1 & $1 / 3$ & 2 & 2 \\
\hline $\begin{array}{l}\text { Vertical } \\
\text { settlement }\end{array}$ & 3 & 6 & 5 & 1 & 1 & 2 & $1 / 2$ & 5 & 3 & 6 & 6 \\
\hline $\begin{array}{l}\text { Column } \\
\text { inclination }\end{array}$ & 4 & 6 & 5 & 1 & 1 & $1 / 2$ & 2 & 5 & 3 & 6 & 6 \\
\hline $\begin{array}{l}\text { Deflection of } \\
\text { beam }\end{array}$ & 5 & 7 & 6 & 2 & 2 & 1 & 3 & 6 & 4 & 7 & 7 \\
\hline $\begin{array}{l}\text { Building } \\
\text { displacement }\end{array}$ & 3 & 5 & 4 & $1 / 2$ & $1 / 2$ & $1 / 3$ & 1 & 4 & 2 & 5 & 5 \\
\hline Roof & $1 / 2$ & $1 / 2$ & 1 & $1 / 5$ & $1 / 5$ & $1 / 6$ & $1 / 4$ & 1 & $1 / 3$ & 2 & 2 \\
\hline Wall & 2 & 4 & 3 & $1 / 3$ & $1 / 3$ & $1 / 4$ & $1 / 2$ & 3 & 1 & 4 & 4 \\
\hline Color drawing & $1 / 3$ & 1 & $1 / 2$ & $1 / 6$ & $1 / 6$ & $1 / 7$ & $1 / 5$ & $1 / 2$ & $1 / 4$ & 1 & 1 \\
\hline Brush pulp & $1 / 3$ & 1 & $1 / 2$ & $1 / 6$ & $1 / 6$ & $1 / 7$ & $1 / 5$ & $1 / 2$ & $1 / 4$ & 1 & 1 \\
\hline
\end{tabular}

Table A2. Relative importance judgment matrix for monitoring indicators of rock heritage

\begin{tabular}{|l|c|c|c|c|}
\hline \multicolumn{1}{|c|}{ Rock Heritage } & Plant influence & Water influence & Human influence & Security and stability \\
\hline Plant influence & 1 & 2 & 3 & $1 / 3$ \\
\hline Water influence & $1 / 2$ & 1 & 3 & $1 / 4$ \\
\hline Human influence & $1 / 3$ & $1 / 3$ & 1 & $1 / 5$ \\
\hline Security and stability & 3 & 4 & 5 & 1 \\
\hline
\end{tabular}


Table A3. Relative importance judgment matrix for monitoring indicators of ancient tree heritage

\begin{tabular}{|l|c|c|c|c|}
\hline \multicolumn{1}{|c|}{ Ancient Tree Heritage } & Growth situation & Site environment & Trauma symptoms & Damage to ancient trees \\
\hline Growth situation & 1 & $1 / 3$ & 2 & $1 / 4$ \\
\hline Site environment & 3 & 1 & 1 & $1 / 3$ \\
\hline Trauma symptoms & $1 / 2$ & $1 / 4$ & 5 & $1 / 5$ \\
\hline Damage to ancient trees & 4 & 3 & 1 \\
\hline
\end{tabular}

Table A4. Relative importance judgment matrix for monitoring indicators of water heritage

\begin{tabular}{|l|c|c|c|}
\hline \multicolumn{1}{|c|}{ Water heritage } & Water area & Water level & $\begin{array}{c}\text { Comprehensive pollution index of } \\
\text { water quality }\end{array}$ \\
\hline Water area & 1 & $1 / 2$ & $1 / 5$ \\
\hline Water level & 2 & 1 & $1 / 3$ \\
\hline Comprehensive pollution index of water quality & 5 & 3 & 1 \\
\hline
\end{tabular}

Table A5. Relative importance judgment matrix for monitoring indicators of furnishing heritage

\begin{tabular}{|l|c|c|c|c|c|}
\hline Furnishing heritage & Degree of damage & Degree of deletion & Position change & Monitoring facilities & Protective facilities \\
\hline Degree of damage & 1 & $1 / 3$ & 3 & $1 / 2$ & 2 \\
\hline Degree of deletion & 3 & 1 & 1 & $1 / 4$ & 4 \\
\hline Position change & $1 / 3$ & $1 / 5$ & 4 & 1 & $1 / 2$ \\
\hline Monitoring facilities & 2 & $1 / 2$ & 2 & $1 / 3$ & 1 \\
\hline Protective facilities & $1 / 2$ & $1 / 4$ & & & 1 \\
\hline
\end{tabular}

Table A6. Weights value of monitoring indicators for garden heritage ontologies

\begin{tabular}{|c|c|c|c|c|c|c|c|c|c|c|c|}
\hline Indicators & \multicolumn{11}{|c|}{ Weight value } \\
\hline \multirow{2}{*}{$\begin{array}{l}\text { Architec- } \\
\text { tural } \\
\text { heritage }\end{array}$} & Scale & Color & $\begin{array}{c}\text { Appea- } \\
\text { rance }\end{array}$ & $\begin{array}{c}\text { Vertical } \\
\text { settlement }\end{array}$ & \begin{tabular}{|c|} 
Column \\
inclination
\end{tabular} & $\begin{array}{l}\text { Deflection } \\
\text { of beam }\end{array}$ & $\begin{array}{c}\text { Building } \\
\text { displacement }\end{array}$ & Roof & Wall & $\begin{array}{c}\text { Color } \\
\text { drawing }\end{array}$ & $\begin{array}{l}\text { Brush } \\
\text { pulp }\end{array}$ \\
\hline & 0.06 & 0.02 & 0.04 & 0.16 & 0.17 & 0.25 & 0.14 & 0.04 & 0.08 & 0.02 & 0.02 \\
\hline \multirow{2}{*}{$\begin{array}{l}\text { Rock } \\
\text { Heritage }\end{array}$} & \multicolumn{3}{|c|}{ Plant influence } & \multicolumn{2}{|c|}{ Water influence } & \multicolumn{2}{|c|}{ Human influence } & \multicolumn{4}{|c|}{ Security and stability } \\
\hline & \multicolumn{3}{|c|}{0.23} & \multicolumn{2}{|c|}{0.16} & \multicolumn{2}{|c|}{0.08} & \multicolumn{4}{|c|}{0.54} \\
\hline Ancient & \multicolumn{3}{|c|}{ Growth situation } & \multicolumn{2}{|c|}{ Site environment } & \multicolumn{2}{|c|}{ Trauma symptoms } & \multicolumn{4}{|c|}{ Damage to ancient trees } \\
\hline Heritage & \multicolumn{3}{|c|}{0.12} & \multicolumn{2}{|c|}{0.27} & \multicolumn{2}{|c|}{0.08} & \multicolumn{4}{|c|}{0.53} \\
\hline \multirow{2}{*}{$\begin{array}{l}\text { Water } \\
\text { heritage }\end{array}$} & \multicolumn{3}{|c|}{ Water area } & \multicolumn{2}{|c|}{ Water level } & \multicolumn{6}{|c|}{ Comprehensive pollution index of water quality } \\
\hline & \multicolumn{3}{|c|}{0.12} & \multicolumn{2}{|c|}{0.23} & \multicolumn{6}{|c|}{0.65} \\
\hline \multirow{2}{*}{$\begin{array}{l}\text { Furnishing } \\
\text { heritage }\end{array}$} & \multicolumn{3}{|c|}{ Degree of damage } & \multicolumn{2}{|c|}{ Degree of deletion } & $\begin{array}{l}\text { Position } \\
\text { change }\end{array}$ & \multicolumn{2}{|c|}{ Monitoring facilities } & \multicolumn{3}{|c|}{ Protective facilities } \\
\hline & \multicolumn{3}{|c|}{0.16} & \multicolumn{2}{|c|}{0.42} & 0.06 & \multicolumn{2}{|l|}{0.26} & \multicolumn{3}{|c|}{0.10} \\
\hline
\end{tabular}

Table A7. Early warning evaluation standard for garden architecture heritage

\begin{tabular}{|l|l|l|l|l|l|}
\hline \multicolumn{2}{|c|}{ Indexes } & \multicolumn{4}{|c|}{ Early Warning grade } \\
\cline { 3 - 6 } & normal (1 point) & \multicolumn{1}{|c|}{ first level (2 points) } & second level (3 points) & \multicolumn{1}{|c|}{ third level (4 points) } \\
\hline $\begin{array}{l}\text { Architecture } \\
\text { appearance }\end{array}$ & scale & $\begin{array}{l}\text { Scale, volume } \\
\text { and elevation } \\
\text { have not changed, } \\
\text { the relationship } \\
\text { between building } \\
\text { and garden } \\
\text { environment has } \\
\text { not changed }\end{array}$ & $\begin{array}{l}\text { Scale, volume and } \\
\text { elevation change } \\
\text { slightly, basically } \\
\text { maintaining the } \\
\text { relationship between } \\
\text { building and garden } \\
\text { environment }\end{array}$ & $\begin{array}{l}\text { Scale, volume and } \\
\text { elevation change } \\
\text { greatly, which affects } \\
\text { the relationship } \\
\text { between building and } \\
\text { garden environment }\end{array}$ & $\begin{array}{l}\text { Large changes have taken } \\
\text { place in scale, volume and } \\
\text { elevation, which seriously } \\
\text { affect the relationship } \\
\text { between building and garden } \\
\text { environment }\end{array}$ \\
\hline
\end{tabular}


End of Table A7

\begin{tabular}{|c|c|c|c|c|c|}
\hline \multirow{2}{*}{\multicolumn{2}{|c|}{ Indexes }} & \multicolumn{4}{|c|}{ Early Warning grade } \\
\hline & & \multirow[b]{2}{*}{\begin{tabular}{|l} 
normal (1 point) \\
No change in \\
color of roof, wall, \\
column, beam \\
frame, door and \\
window, no effect \\
on architectural \\
style and \\
authenticity
\end{tabular}} & \multirow[b]{2}{*}{$\begin{array}{l}\text { first level (2 points) } \\
\text { Color of roof, wall, } \\
\text { column, beam frame, } \\
\text { door and window } \\
\text { changes partly, no } \\
\text { effect on overall } \\
\text { architectural style and } \\
\text { authenticity }\end{array}$} & \multirow[b]{2}{*}{\begin{tabular}{|l|} 
second level (3 points) \\
Color of roof, wall, \\
column, beam frame, \\
door and window \\
changes in large areas, \\
which affects the \\
overall architectural \\
style and authenticity \\
\end{tabular}} & \multirow[b]{2}{*}{$\begin{array}{l}\text { third level (4 points) } \\
\text { Color of roof, wall, column, } \\
\text { beam frame, door and } \\
\text { window changes too much, } \\
\text { overall architectural style is } \\
\text { damaged, the authenticity is } \\
\text { missing }\end{array}$} \\
\hline & Color & & & & \\
\hline & Appearance & $\begin{array}{l}\text { Appearance of } \\
\text { roof, corner } \\
\text { warping, door and } \\
\text { window shape, } \\
\text { beam frame, etc. } \\
\text { has no change, } \\
\text { maintained } \\
\text { authenticity } \\
\end{array}$ & $\begin{array}{l}\text { Small changes happen } \\
\text { in the shape of roof } \\
\text { decoration, corner } \\
\text { warping, door and } \\
\text { window, beam frame, } \\
\text { etc. No effect on } \\
\text { overall authenticity }\end{array}$ & $\begin{array}{l}\text { Appearance of roof } \\
\text { decoration, corner } \\
\text { warping, door and } \\
\text { window shape, beam } \\
\text { frame, etc. has changed } \\
\text { greatly, which affects } \\
\text { the authenticity }\end{array}$ & $\begin{array}{l}\text { Large changes to the shape } \\
\text { of roof decoration, corner } \\
\text { warping, door and window, } \\
\text { beam frame, etc. Seriously } \\
\text { affecting the authenticity }\end{array}$ \\
\hline \multirow[t]{6}{*}{$\begin{array}{l}\text { Architecture } \\
\text { structure }\end{array}$} & $\begin{array}{l}\text { Vertical } \\
\text { settlement }\end{array}$ & $\begin{array}{l}\text { Settlement } \\
\text { rate is between } \\
-0.01 \mathrm{~mm} / \mathrm{d} \text { and } \\
0.005 \mathrm{~mm} / \mathrm{d}\end{array}$ & $\begin{array}{l}\text { Settlement rate is } \\
\text { between }-0.01 \mathrm{~mm} / \mathrm{d} \\
\text { and }-0.08 \mathrm{~mm} / \mathrm{d} \\
\text { or } 0.005 \mathrm{~mm} / \mathrm{d} \text { and } \\
0.03 \mathrm{~mm} / \mathrm{d}\end{array}$ & $\begin{array}{l}\text { Settlement rate is } \\
\text { between }-0.08 \mathrm{~mm} / \mathrm{d} \\
\text { and }-0.15 \mathrm{~mm} / \mathrm{d} \\
\text { or } 0.03 \mathrm{~mm} / \mathrm{d} \text { and } \\
0.08 \mathrm{~mm} / \mathrm{d}\end{array}$ & $\begin{array}{l}\text { Settlement rate is greater than } \\
-0.15 \mathrm{~mm} / \mathrm{d} \text { or } 0.08 \mathrm{~mm} / \mathrm{d}\end{array}$ \\
\hline & $\begin{array}{l}\text { Column } \\
\text { inclination }\end{array}$ & $\begin{array}{l}\text { Change value is } \\
\text { less than } 10 \mathrm{~mm}\end{array}$ & $\begin{array}{l}\text { Change value is } \\
\text { between } 10 \text { and } 30 \mathrm{~mm}\end{array}$ & $\begin{array}{l}\text { Change value is } \\
\text { between } 30 \text { ando } \\
60 \mathrm{~mm}\end{array}$ & $\begin{array}{l}\text { Change value is greater than } \\
60 \mathrm{~mm}\end{array}$ \\
\hline & $\begin{array}{l}\text { Deflection of } \\
\text { beam }\end{array}$ & $\begin{array}{l}\text { Change value is } \\
\text { less than } 5 \mathrm{~mm}\end{array}$ & $\begin{array}{l}\text { Change value is } \\
\text { between } 5 \text { and } 10 \mathrm{~mm}\end{array}$ & $\begin{array}{l}\text { Change value is } \\
\text { between } 10 \text { and } 20 \mathrm{~mm}\end{array}$ & $\begin{array}{l}\text { Change value is greater than } \\
20 \mathrm{~mm}\end{array}$ \\
\hline & $\begin{array}{l}\text { Building } \\
\text { displacement }\end{array}$ & $\begin{array}{l}\text { Change value is } \\
\text { less than } 5 \mathrm{~mm}\end{array}$ & $\begin{array}{l}\text { Change value is } \\
\text { between } 5 \text { and } 10 \mathrm{~mm}\end{array}$ & $\begin{array}{l}\text { Change value is } \\
\text { between } 10 \text { and } 20 \mathrm{~mm}\end{array}$ & $\begin{array}{l}\text { Change value is greater than } \\
20 \mathrm{~mm}\end{array}$ \\
\hline & Roof & $\begin{array}{l}\text { No leakage on } \\
\text { roof, tile and } \\
\text { ridge are in good } \\
\text { condition, no } \\
\text { weeds on roof }\end{array}$ & $\begin{array}{l}\text { Roof is covered with } \\
\text { grass, ridge and tile are } \\
\text { slightly damaged }\end{array}$ & $\begin{array}{l}\text { Small cracks on roof } \\
\text { allow some rain } \\
\text { leakage, roof ridge and } \\
\text { tile are damaged }\end{array}$ & $\begin{array}{l}\text { Roof rain leakage area is } \\
\text { large, tile and ridge are } \\
\text { seriously broken }\end{array}$ \\
\hline & Wall & $\begin{array}{l}\text { Wall is intact } \\
\text { without } \\
\text { inclination }\end{array}$ & $\begin{array}{l}\text { Some walls are } \\
\text { deformed and some } \\
\text { windows are damaged }\end{array}$ & $\begin{array}{l}\text { Deformation of wall } \\
\text { is serious, or wall is } \\
\text { weathered and caustic }\end{array}$ & $\begin{array}{l}\text { Wall is weathered and caustic, } \\
\text { wall body is tilted seriously, } \\
\text { leaking window is damaged }\end{array}$ \\
\hline \multirow[t]{2}{*}{$\begin{array}{l}\text { Architecture } \\
\text { decoration }\end{array}$} & $\begin{array}{l}\text { Color } \\
\text { painting }\end{array}$ & $\begin{array}{l}\text { Color painting } \\
\text { is not fading, } \\
\text { cracking, warping } \\
\text { or falling }\end{array}$ & $\begin{array}{l}\text { Color painting has } \\
\text { fading reaction or } \\
\text { small cracks }\end{array}$ & $\begin{array}{l}\text { Color painting has } \\
\text { obvious fading, } \\
\text { cracking, warping and } \\
\text { falling off }\end{array}$ & $\begin{array}{l}\text { Color painting is seriously } \\
\text { fading, cracking, warping and } \\
\text { falling off }\end{array}$ \\
\hline & Brush pulp & $\begin{array}{l}\text { No peeling } \\
\text { damage or change } \\
\text { in brush pulp }\end{array}$ & $\begin{array}{l}\text { Smudging, mildew and } \\
\text { discoloration happen } \\
\text { partly in brush pulp }\end{array}$ & $\begin{array}{l}\text { Brush pulp is peeling, } \\
\text { damaged and } \\
\text { corroding }\end{array}$ & $\begin{array}{l}\text { A large area of peeling and } \\
\text { serious damage to brush pulp }\end{array}$ \\
\hline
\end{tabular}




\begin{tabular}{|c|c|c|c|c|c|c|}
\hline 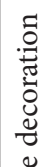 & 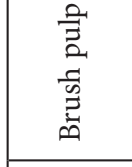 & 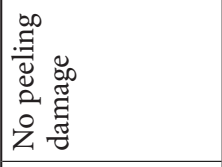 & 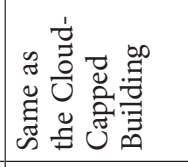 & 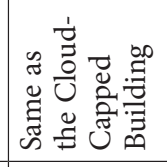 & 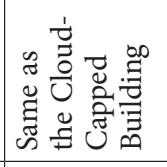 & 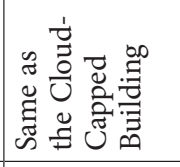 \\
\hline 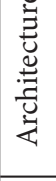 & 咅 & 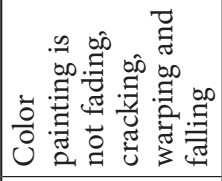 & 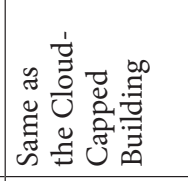 & 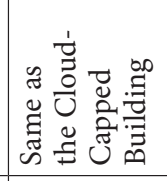 & 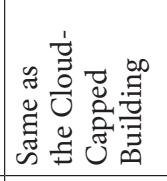 & 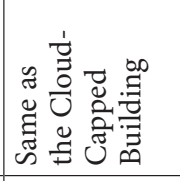 \\
\hline \multirow{6}{*}{ 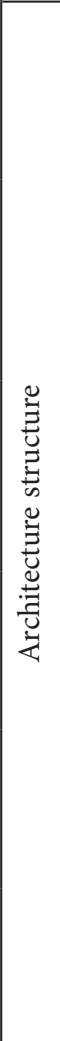 } & 窝 & 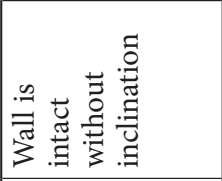 & 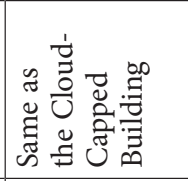 & 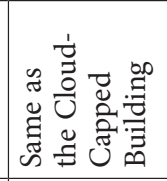 & 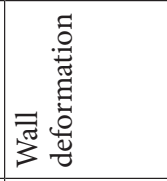 & 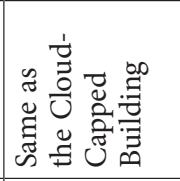 \\
\hline & $\begin{array}{l}\text { 苍 } \\
\stackrel{0}{a}\end{array}$ & 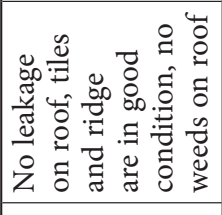 & 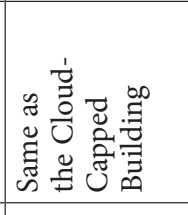 & 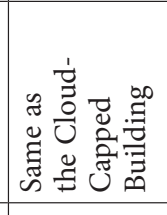 & 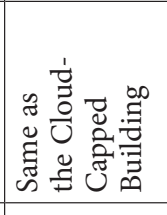 & 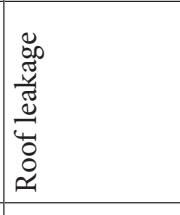 \\
\hline & 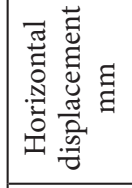 & in & 0 & $\neg$ & $\overrightarrow{+}$ & in \\
\hline & 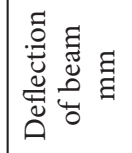 & $\stackrel{\sim}{ }$ & 아 & $m$ & $\stackrel{n}{+}$ & $\stackrel{-}{\circ}$ \\
\hline & 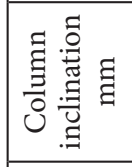 & $\ddot{\sim}$ & $\stackrel{20}{-1}$ & iి & กี & $\stackrel{\sim}{\beth}$ \\
\hline & 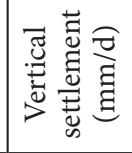 & $\begin{array}{l}\infty \\
\tilde{o} \\
\vdots \\
0 \\
0\end{array}$ & $\begin{array}{l}\infty \\
\vdots \\
0 \\
0 \\
0 \\
1\end{array}$ & ت्ञ & $\begin{array}{l}\tilde{o} \\
\vdots \\
0 \\
i\end{array}$ & 官 \\
\hline \multirow{3}{*}{ 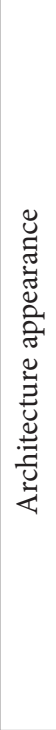 } & 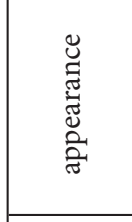 & 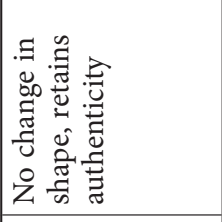 & 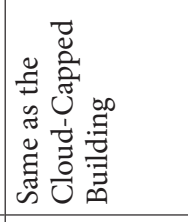 & 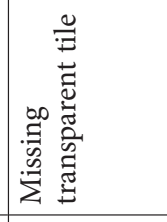 & 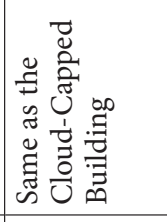 & 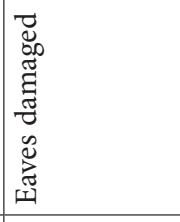 \\
\hline & $\frac{\tilde{0}}{8}$ & 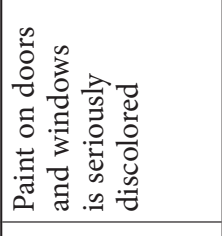 & 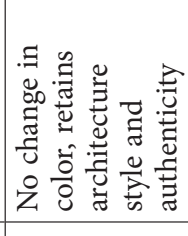 & 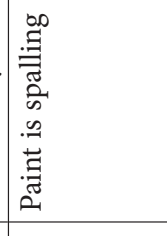 & 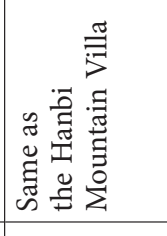 & 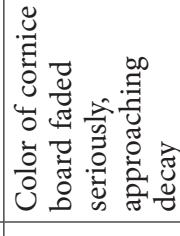 \\
\hline & 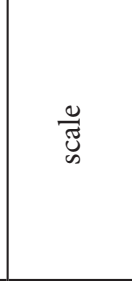 & 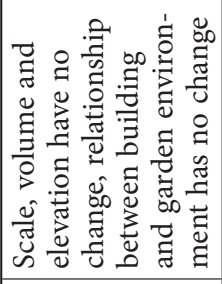 & 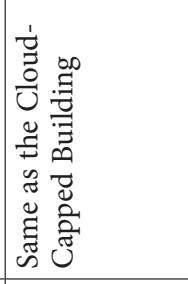 & 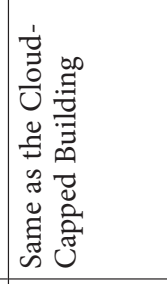 & 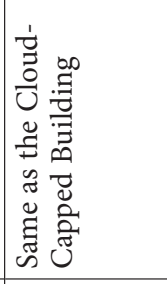 & 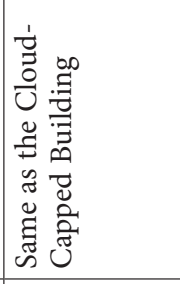 \\
\hline & ঠ் & 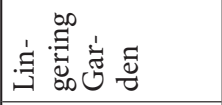 & 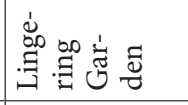 & 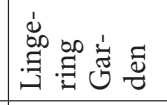 & 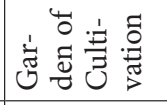 & 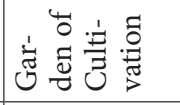 \\
\hline & 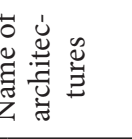 & 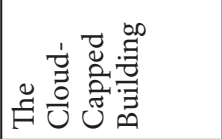 & 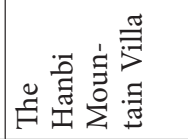 & 莺昜 & 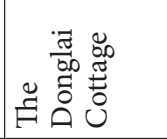 & 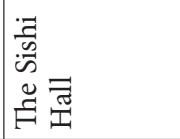 \\
\hline
\end{tabular}


Table A9. Quantified garden architecture heritage monitoring data

\begin{tabular}{|c|c|c|c|c|c|c|c|c|c|c|c|c|}
\hline \multirow{2}{*}{$\begin{array}{c}\text { Name of } \\
\text { garden } \\
\text { architecture }\end{array}$} & \multirow{2}{*}{ Location } & \multicolumn{3}{|c|}{$\begin{array}{l}\text { Architecture } \\
\text { appearance }\end{array}$} & \multicolumn{6}{|c|}{ Architecture structure } & \multicolumn{2}{|c|}{$\begin{array}{l}\text { Architecture } \\
\text { decoration }\end{array}$} \\
\hline & & scale & color & $\begin{array}{l}\text { appea- } \\
\text { rance }\end{array}$ & $\begin{array}{l}\text { Vertical } \\
\text { settlement } \\
(\mathrm{mm} / \mathrm{d})\end{array}$ & $\begin{array}{l}\text { Column } \\
\text { inclination } \\
\mathrm{mm}\end{array}$ & $\begin{array}{c}\text { Deflection } \\
\text { of beam } \\
\text { mm }\end{array}$ & $\begin{array}{c}\text { Horizontal } \\
\text { displacement } \\
\mathrm{mm}\end{array}$ & Roof & Wall & $\begin{array}{l}\text { Color } \\
\text { dra- } \\
\text { wing }\end{array}$ & $\begin{array}{l}\text { Brush } \\
\text { pulp }\end{array}$ \\
\hline $\begin{array}{l}\text { The Cloud- } \\
\text { Capped } \\
\text { Building }\end{array}$ & $\begin{array}{l}\text { Lingering } \\
\text { Garden }\end{array}$ & 1 & 3 & 1 & 0.0038 & 23 & 20 & 5 & 1 & 1 & 1 & 1 \\
\hline $\begin{array}{l}\text { The Hanbi } \\
\text { Mountain } \\
\text { Villa }\end{array}$ & $\begin{array}{l}\text { Lingering } \\
\text { Garden }\end{array}$ & 1 & 1 & 1 & -0.0008 & 15 & 49 & 0 & 1 & 1 & 1 & 1 \\
\hline $\begin{array}{l}\text { The Pellucid } \\
\text { Building }\end{array}$ & $\begin{array}{l}\text { Lingering } \\
\text { Garden }\end{array}$ & 1 & 2 & 4 & -0.0011 & 30 & 3 & 1 & 1 & 1 & 1 & 1 \\
\hline $\begin{array}{l}\text { The Donglai } \\
\text { Cottage }\end{array}$ & $\begin{array}{l}\text { Garden } \\
\text { of Culti- } \\
\text { vation }\end{array}$ & 1 & 1 & 1 & -0.002 & 22 & 14.5 & 4.1 & 1 & 3 & 1 & 1 \\
\hline $\begin{array}{l}\text { The Sishi } \\
\text { Hall }\end{array}$ & $\begin{array}{l}\text { Garden } \\
\text { of Culti- } \\
\text { vation }\end{array}$ & 1 & 2 & 2 & 0.001 & 12 & 10 & 5.2 & 2 & 1 & 1 & 1 \\
\hline
\end{tabular}

Table A10. Statistics for ancient trees in the Lingering Garden

\begin{tabular}{|c|c|c|c|c|c|c|c|c|}
\hline $\begin{array}{l}\text { Num- } \\
\text { bers }\end{array}$ & Name & Position & Height & $\begin{array}{l}\text { Bust } \\
(\mathrm{cm})\end{array}$ & $\begin{array}{l}\text { Base } \\
\text { girth } \\
(\mathrm{cm})\end{array}$ & $\begin{array}{l}\text { Crown } \\
\text { width }\end{array}$ & $\begin{array}{l}\text { Tree } \\
\text { age } \\
\text { (year) }\end{array}$ & Growth situation \\
\hline M-1 & $\begin{array}{l}\text { No. 002\# } \\
\text { Ginkgo biloba } \\
\text { Linn. }\end{array}$ & $\begin{array}{l}\text { West of } \\
\text { central pool }\end{array}$ & $25 \mathrm{~m}$ & 340 & 370 & $17.2 \times 17.9 \mathrm{~m}$ & 343 & $\begin{array}{l}\text { Growth potential is strong, there are } \\
\text { a few dead branches in the crown, } \\
\text { inclination of tree is obvious. }\end{array}$ \\
\hline M-2 & $\begin{array}{l}\text { No. 003\# } \\
\text { Ginkgo biloba } \\
\text { Linn. }\end{array}$ & $\begin{array}{l}\text { West of } \\
\text { central the } \\
\text { Satisfaction } \\
\text { Pavilion }\end{array}$ & $20 \mathrm{~m}$ & 253 & 350 & $14.8 \times 15.1 \mathrm{~m}$ & 243 & $\begin{array}{l}\text { Growth potential is strong, but some } \\
\text { thick roots are bare, and tree inclines } \\
\text { obviously. }\end{array}$ \\
\hline M-3 & $\begin{array}{l}\text { Lagerstroemia } \\
\text { subcostata } \\
\text { Koehne }\end{array}$ & $\begin{array}{l}\text { Northwest } \\
\text { of central } \\
\text { rockery }\end{array}$ & $9.5 \mathrm{~m}$ & 150 & 220 & $10 \times 9 \mathrm{~m}$ & 240 & $\begin{array}{l}\text { Growth potential is general, the main } \\
\text { trunk is slightly inclined to the north, } \\
\text { lateral roots are exposed. }\end{array}$ \\
\hline M-5 & $\begin{array}{l}\text { Magnolia } \\
\text { grandiflora } \\
\text { Linn. }\end{array}$ & $\begin{array}{l}\text { Northeast of } \\
\text { gate of Youyi } \\
\text { village }\end{array}$ & $17 \mathrm{~m}$ & 260 & 290 & $15 \times 12 \mathrm{~m}$ & 150 & Growth potential is strong. \\
\hline M-9 & $\begin{array}{l}\text { Platycladus } \\
\text { orientalis } \\
\text { (Linn.) }\end{array}$ & $\begin{array}{l}\text { Southwest of } \\
\text { central pool }\end{array}$ & $5 \mathrm{~m}$ & 90 & 93 & $4 \times 4 \mathrm{~m}$ & 320 & $\begin{array}{l}\text { Growth potential is weak. Leaves } \\
\text { are gray and yellowish, dead ends } \\
\text { are serious, there are many dead } \\
\text { branches, upper crown withers. Trunk } \\
\text { inclines to the south. }\end{array}$ \\
\hline M-14 & $\begin{array}{l}\text { Podocarpus } \\
\text { macrophyllus } \\
\text { (Thunb.) Sweet }\end{array}$ & $\begin{array}{l}\text { Northeast of } \\
\text { south yard } \\
\text { of Yifeng } \\
\text { pavilion }\end{array}$ & $6 \mathrm{~m}$ & 80 & 85 & $4 \times 4 \mathrm{~m}$ & 113 & $\begin{array}{l}\text { Growth potential is weak, main trunk } \\
\text { cracked into two pieces, south half } \\
\text { withered, tree top once cut off, the } \\
\text { sprouting branches formed a cluster } \\
\text { similar to a crown. }\end{array}$ \\
\hline
\end{tabular}


Table A11. Water quality monitoring report of the Suzhou Classic Garden

\begin{tabular}{|c|c|c|c|c|c|c|c|c|c|c|}
\hline Sample locations & $\begin{array}{l}\mathrm{BOD}_{5} \\
\mathrm{mg} / \mathrm{L}\end{array}$ & $\begin{array}{c}\mathrm{PH} \\
\text { value }\end{array}$ & $\begin{array}{l}\text { Ammonia } \\
\text { nitrogen } \\
\mathrm{mg} / \mathrm{L}\end{array}$ & $\begin{array}{l}\text { Permanganate } \\
\text { index } \\
\mathrm{mg} / \mathrm{L}\end{array}$ & $\begin{array}{l}\text { Dissolved } \\
\text { oxygen } \\
\text { mg/L }\end{array}$ & $\begin{array}{c}\text { Chro- } \\
\text { ma }\end{array}$ & $\begin{array}{l}\text { Transpa- } \\
\text { rency }\end{array}$ & $\begin{array}{l}\text { Total } \\
\text { phos- } \\
\text { phorus } \\
\text { mg/L }\end{array}$ & $\begin{array}{l}\text { Tem- } \\
\text { pera- } \\
\text { ture }^{\circ}\end{array}$ & $\begin{array}{l}\text { Compre- } \\
\text { hensive } \\
\text { pollution } \\
\text { index } \\
\text { of water } \\
\text { quality }\end{array}$ \\
\hline $\begin{array}{l}\text { Central pool of } \\
\text { Lingering Garden }\end{array}$ & 4.4 & 7.48 & 0.228 & 3.3 & 3.94 & 2 & 119 & 0.06 & 20.8 & 0 \\
\hline $\begin{array}{l}\text { Huanyun billabong, } \\
\text { east of Lingering } \\
\text { Garden }\end{array}$ & 1.5 & 7.38 & 0.228 & 5.3 & 3.78 & 2 & 128 & 0.40 & 20.2 & 40 \\
\hline $\begin{array}{l}\text { Western stream of } \\
\text { Lingering Garden }\end{array}$ & 1.3 & 7.31 & 0.930 & 3.8 & 3.54 & 2 & 155 & 0.80 & 19.9 & 80 \\
\hline $\begin{array}{l}\text { Central pond } \\
\text { in Garden of } \\
\text { Cultivation }\end{array}$ & 4.2 & 8.88 & 0.392 & 4.4 & 4.92 & 8 & 65 & 0.17 & 20.9 & 0 \\
\hline $\begin{array}{l}\text { Mid-lake Pavilion of } \\
\text { Lion Forest Garden }\end{array}$ & 1.8 & 7.40 & 0.990 & 3.7 & 4.25 & 2 & 106 & 1.32 & 20.1 & 190 \\
\hline $\begin{array}{l}\text { Internal pool of } \\
\text { Gentle Waves } \\
\text { Pavilion }\end{array}$ & 1.3 & 7.44 & 0.520 & 4.0 & 3.49 & 2 & 150 & 0.12 & 20.0 & 0 \\
\hline $\begin{array}{l}\text { Rosy clouds pool } \\
\text { of Master-of-Nets } \\
\text { Garden }\end{array}$ & 2.0 & 8.16 & 0.203 & 2.6 & 3.94 & 2 & 158 & 0.54 & 20.2 & 54 \\
\hline$\ldots$ & $\ldots$ & $\ldots$ & $\ldots$ & $\cdots$ & $\ldots$ & $\ldots$ & $\ldots$ & $\ldots$ & $\ldots$ & \\
\hline
\end{tabular}

Table A12. Quantified water heritage monitoring data

\begin{tabular}{|l|c|c|c|}
\hline \multirow{2}{*}{\multicolumn{1}{c|}{ Sample locations }} & \multicolumn{2}{c|}{ Change of water form } & Water quality \\
\cline { 2 - 4 } & water area & water level & comprehensive pollution index \\
\hline Western stream of Lingering Garden & 1 & 3 & 80 \\
\hline Central pool of Lingering Garden & 1 & 1 & 0 \\
\hline Huanyun billabong in the east of Lingering Garden & 1 & 1 & 40 \\
\hline Central pond in Garden of Cultivation & 1 & 1 & 0 \\
\hline Internal pool of Gentle Waves Pavilion & 1 & 2 & 0 \\
\hline Rosy clouds pool of Master-of-Nets Garden & 1 & 1 & 54 \\
\hline Mid-lake Pavilion of Lion Forest Garden & 2 & 3 & 190 \\
\hline
\end{tabular}

